ВІСНИК

ОДЕСЬКОГО НАЦІОНАЛЬНОГО

МОРСЬКОГО УНІВЕРСИТЕТУ

№ 2 (59), 2019
HERALD

OF THE ODESSA NATIONAL

MARITIME UNIVERSITY № 2 (59), 2019

629.5.01

DOI 10.33082/2226-1915 -2-2019-41-76

\title{
МОДЕРНИЗАЦИЯ И КОНВЕРСИЯ РЕЧНЫХ КРУИЗНЫХ ПАССАЖИРСКИХ СУДОВ
}

\author{
А.Г. Егоров \\ к.т.н., ст. научн. сотрудник \\ Морское инженерное бюро, г. Одеса
}

В статье приведены примеры реализации на практике модернизачии и конверсии речных круизных пассажсирских судов, выполненные по проектам Морского Инженерного Бюро. Отмечены особенности таких работ. Показаны результаты модернизации и конверсии.

Ключевые слова: речное пассажирское судно, круиз, модернизачия, конверсия, внедрение, инновачия, комфортабельность, безопасность.

УДК 629.5.01

DOI 10.33082/2226-1915 -2-2019-41-76

\section{МОДЕРНІЗАЦІЯ ТА КОНВЕРСІЯ РІЧКОВИХ КРУЇЗНИХ ПАСАЖИРСЬКИХ СУДЕН}

\author{
О.Г. Єгоров \\ к.т.н., ст. наук. співпрацівник \\ Морське інженерне бюро, м. Одеса
}

У статті наведено приклади реалізаиії на практииі модернізації та конверсї річкових круїзних пасажсирських суден, які були виконані по проектах Морського Інженерного Бюро. Відзначено особливості таких робіт. Показано результати модернізаиії й конверсії.

Ключові слова: річкове пасажирське судно, круїз, модернізачія, конверсія, впровадження, інновачія, комфортабельність, безпека.

UDC 629.5.01

DOI 10.33082/2226-1915 -2-2019-41-76

\section{MODERNIZATION AND CONVERSION OF RIVER CRUISE PASSENGER VESSELS}

\author{
A.G. Egorov
}

Candidate of Technical Sciences, Senior Researcher

Marime Engineering Bureau, Odessa

Егоров А.Г., 2019 
In paper examples of realization on practice of modernization and conversion of river cruise passenger vessels completed according to Marine Engineering Bureau projects are given. Features of such works are noted. Results of modernization and conversion are shown.

Keywords: river passenger vessel, cruise, modernization, conversion, implementation, innovation, comfortableness, safety.

Постановка проблемы. Речные круизы являются популярной разновидностью туризма и развиты во всем мире. Помимо существующих круизов в Европе, США, Китае, Египте, России и Украине появляются новые круизы по небольшим рекам Европы (включая Беларусь, Португалию, Францию), Южной Америке, Вьетнаму, Камбодже и т.п. [3]. Кроме диверсификации круизов, повышается также качество самих речных круизных пассажирских судов (РКПС) [1]. Всё это - результат учета потребностей клиентов, которые становятся более требовательными к уровню обеспечения отдыха.

Отечественные РКПС, помимо того, что удовлетворяют потребности «своих» туристов в круизах, являются, в том числе, звеньями мировой круизной цепи. На нашем рынке работают такие операторы как Viking River Cruises, Scenic Tours и многие другие, которые продают круизы по Днепру и Волге как часть составного большого тура, который очень популярен у иностранных туристов.

С каждым годом флот РКПС стареет, причем в первую очередь, морально-технологический процесс не стоит на месте, и даже десятилетние европейские круизные пассажирские суда подвергаются модернизации, чтобы выдерживать конкуренцию на рынке [13].

Операторы же отечественных РКПС, учитывая короткую навигацию и другие проблемы экономического и логистического характера [4], не имеют возможности столь динамично реагировать на изменения рынка. Тем не менее, как показывает прогноз А.Г. Егорова [2], флот отечественных РКПС существенно сократится в ближайшие 10 лет, тем самым сократится и объем пассажирских круизных перевозок, в том числе, иностранных туристов.

Выходом из ситуации на ближайшую перспективу может служить модернизация и конверсия РКПС. Модернизация, в отечественных условиях, позволит продлить срок службы РКПС на 10-15 лет, конверсия - на 20-25 лет [5].

Целью статьи является описание уже реализованных примеров модернизации и конверсии отечественных РКПС, в том числе, по проектам Морского Инженерного Бюро, с выявлением основных результатов работы.

Изложение основного материала. «Княжна Виктория» (модернизация РКПС проекта 301). В 2010-2011 годах компанией «Московский туристический флот» была выполнена модернизация теплохода 
ВІСНИК

ОДЕСЬКОГО НАЦІОНАЛЬНОГО

МОРСЬКОГО УНІВЕРСИТЕТУ

№ 2 (59), 2019
HERALD

OF THE ODESSA NATIONAL

MARITIME UNIVERSITY № 2 (59), 2019

«Александр Грибоедов» 1982 года постройки (проект 301). После модернизации судно получило название «Княжна Виктория».

План палуб РКПС после модернизации представлен на рисунке 1. «Княжна Виктория» после модернизации позиционируется как 4* отель.

G wanter

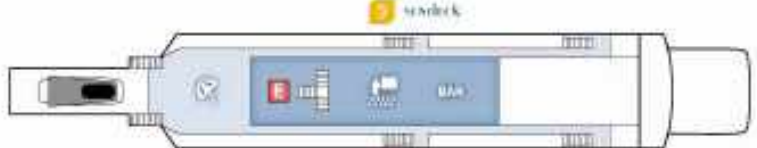

(1) suliguders

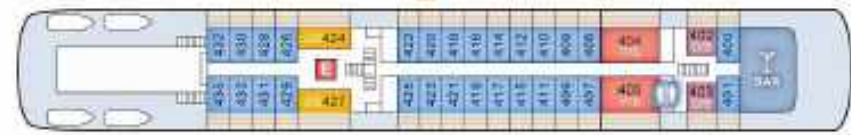

(9) wrotion

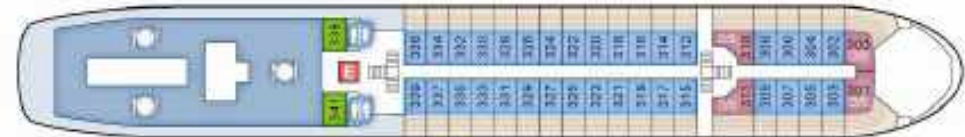

2] wingus lich

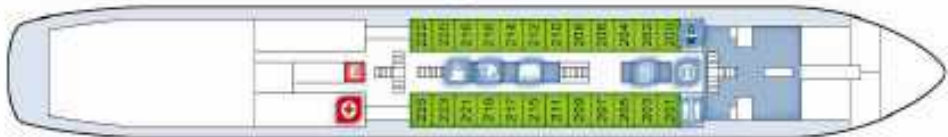

Nenis ines

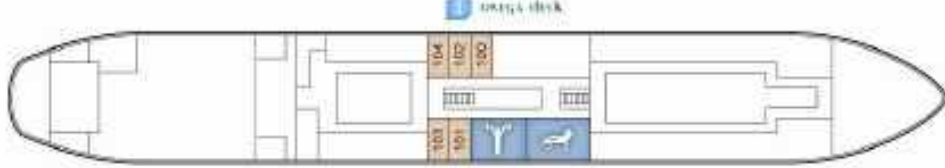

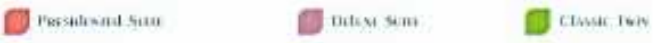

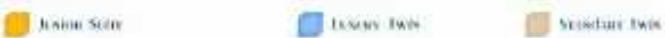

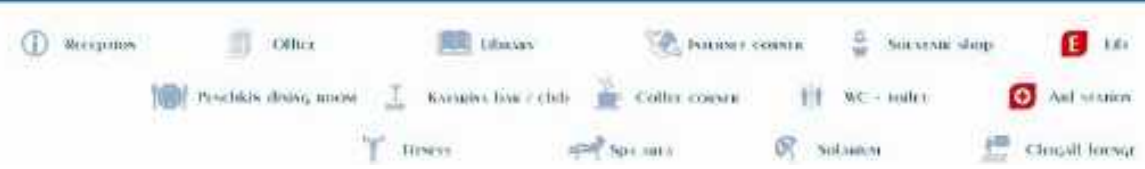

Рис. 1. План палуб $m / x$ «Княжна Виктория»

Были полностью демонтированы внутренние конструкции пассажирских помещений теплохода (см. рисунок 2), вместо окон на шлюпочной и средней палубах врезаны балконные блоки (см. рисунок 3), произведена термоизоляция внешних стен (см. рисунок 4), изготовлены перегородки и двери новых кают и коридоров из панелей класса В15 (см. рисунок 5).

За счет сокращения пассажировместимости площадь стандартных кают увеличилась до 15-25 м². 
ВІСНИК

ОДЕСЬКОГО НАЦІОНАЛЬНОГО

МОРСЬКОГО УНІВЕРСИТЕТУ

№ 2 (59), 2019
HERALD

OF THE ODESSA NATIONAL

MARITIME UNIVERSITY

№ 2 (59), 2019

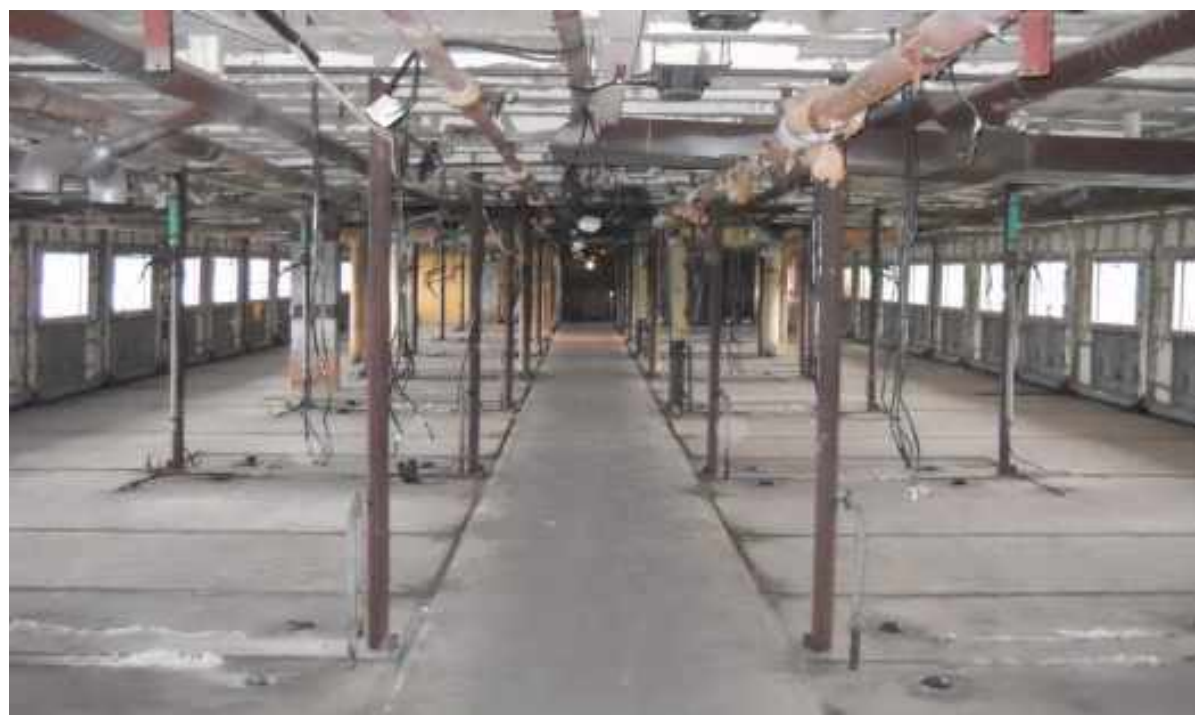

Рис. 2. Демонтаж внутренних конструкций пассажирских помещений теплохода

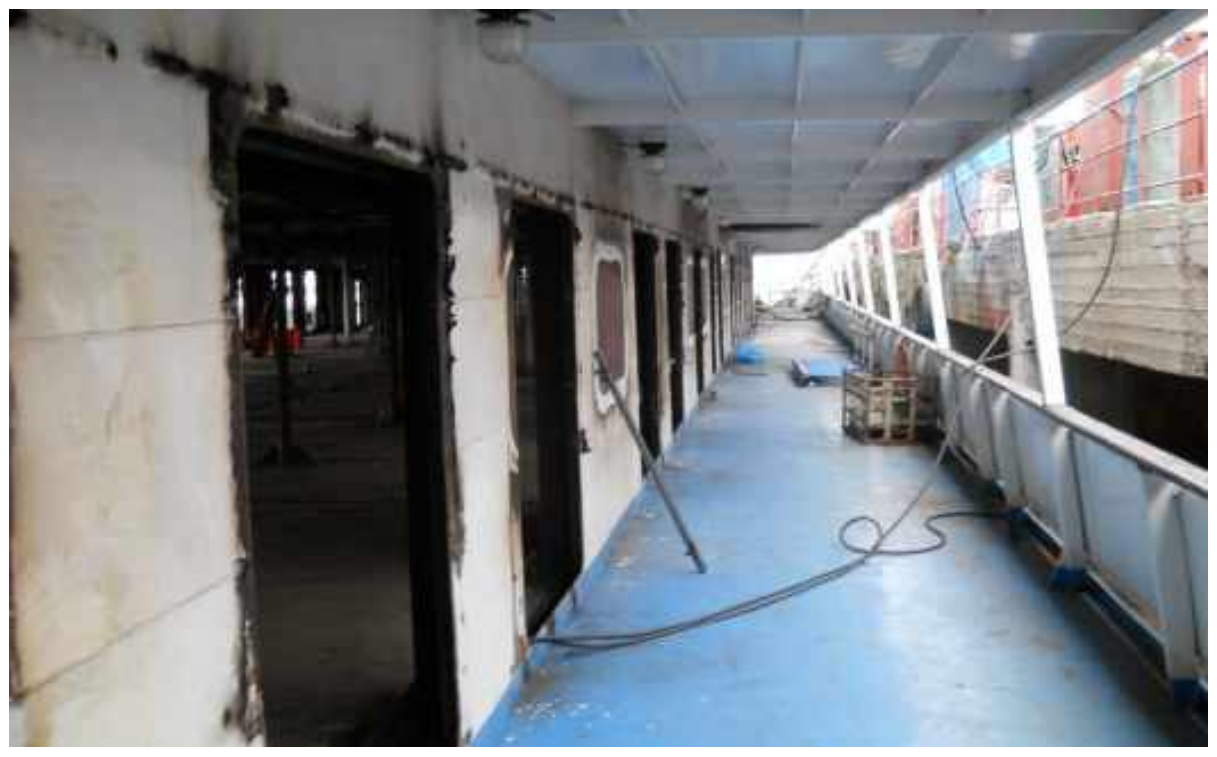

Рис. 3. Врезка балконных блоков (вместо окон) на шлюпочной и средней палубах 
ВІСНИК

ОДЕСЬКОГО НАЦІОНАЛЬНОГО

МОРСЬКОГО УНІВЕРСИТЕТУ

№ 2 (59), 2019
HERALD

OF THE ODESSA NATIONAL

MARITIME UNIVERSITY

№ 2 (59), 2019

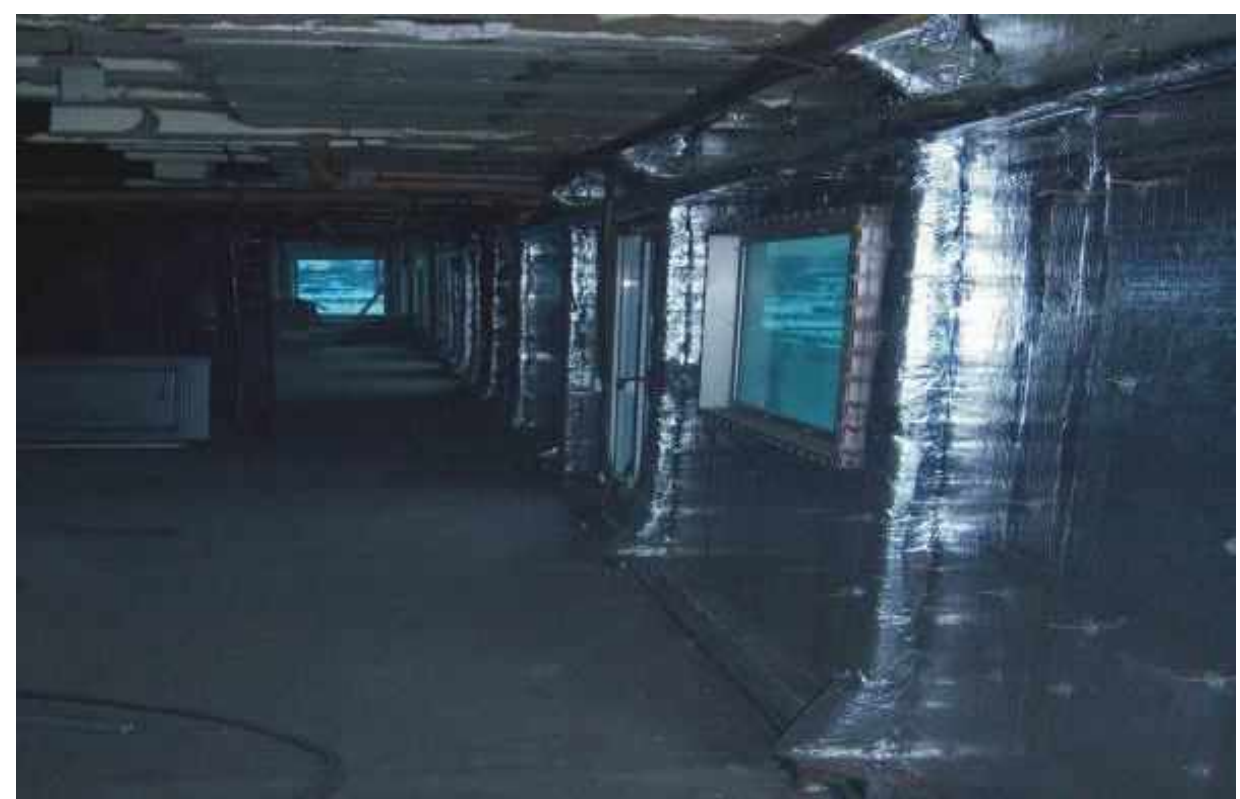

Рис. 4. Термоизоляция внешних стен

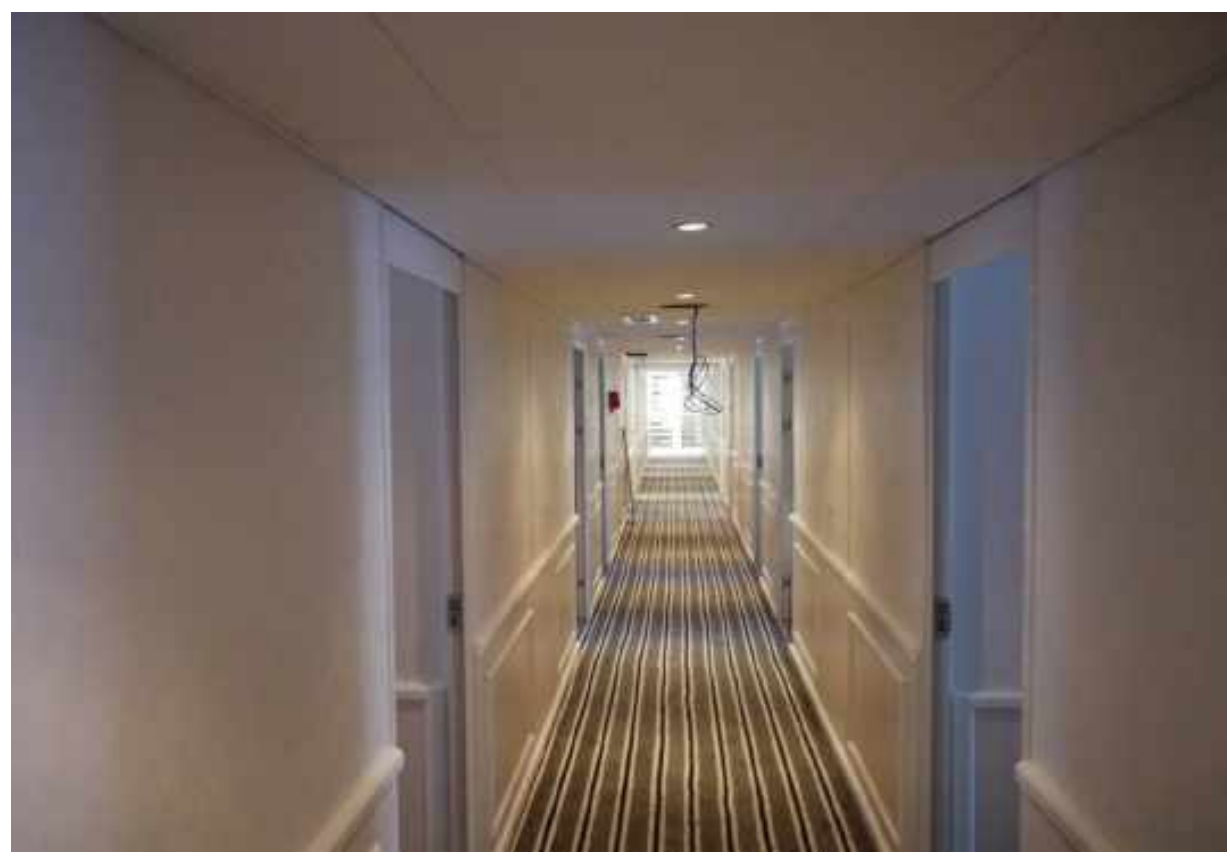

Рис. 5. Перегородки и двери новых кают и коридоров из панелей класса В15 
ВІСНИК

ОДЕСЬКОГО НАЦІОНАЛЬНОГО

МОРСЬКОГО УНІВЕРСИТЕТУ № 2 (59), 2019
HERALD

OF THE ODESSA NATIONAL

MARITIME UNIVERSITY № 2 (59), 2019

Большая часть кают имеют собственные балконы (см. рисунок 6).

Каюты оборудованы как аналогичные номера береговых отелей (см. рисунок 7).

Предусмотрены спутниковое телевидение и Wi-Fi (см. рисунок 8), холодильники с мини-барами, системы управления климатом (см. рисунок 9), телефоны, каютные сейфы, фены.

Кроме того, на судне установлены лифты, приспособленные для людей с ограниченными возможностями (см. рисунок 10).

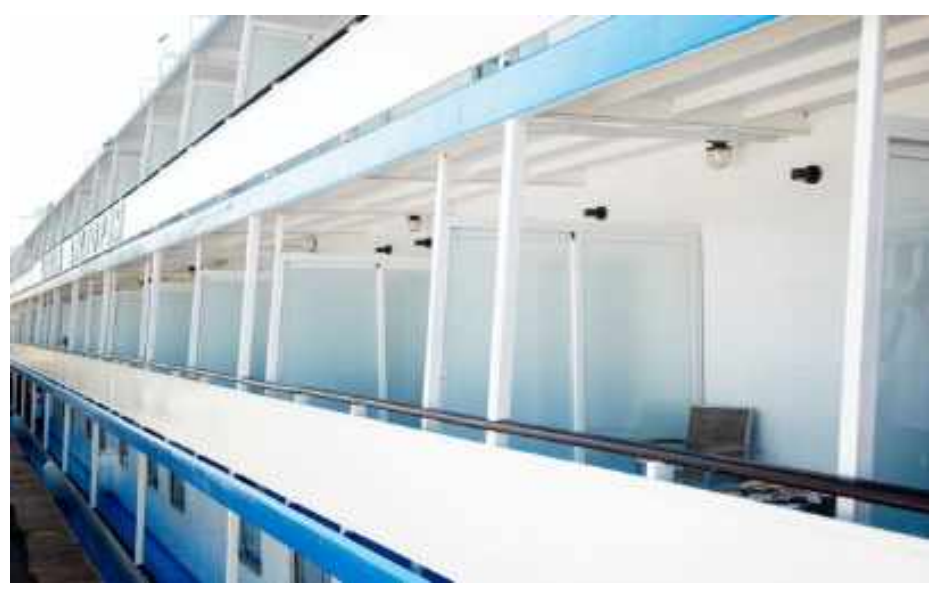

Рис. 6. Балконы кают

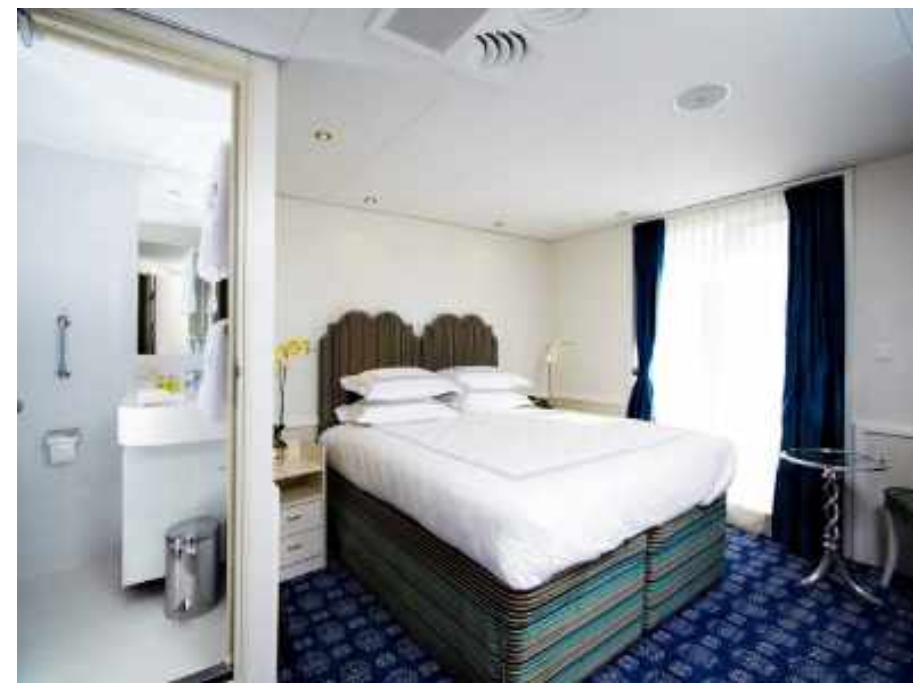

Рис. 7. Интерьер каюты 
ВІСНИК

ОДЕСЬКОГО НАЦІОНАЛЬНОГО

МОРСЬКОГО УНІВЕРСИТЕТУ

№ 2 (59), 2019
HERALD

OF THE ODESSA NATIONAL

MARITIME UNIVERSITY № 2 (59), 2019

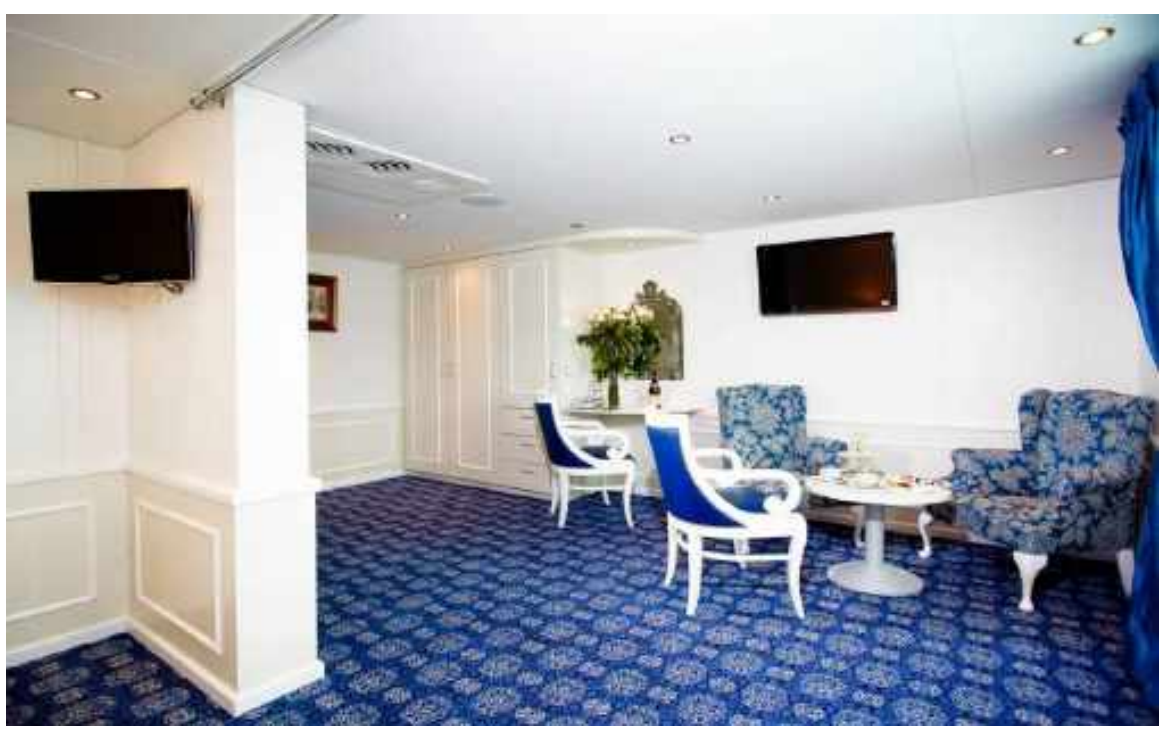

Рис. 8. Телевидение, телефон и интернет

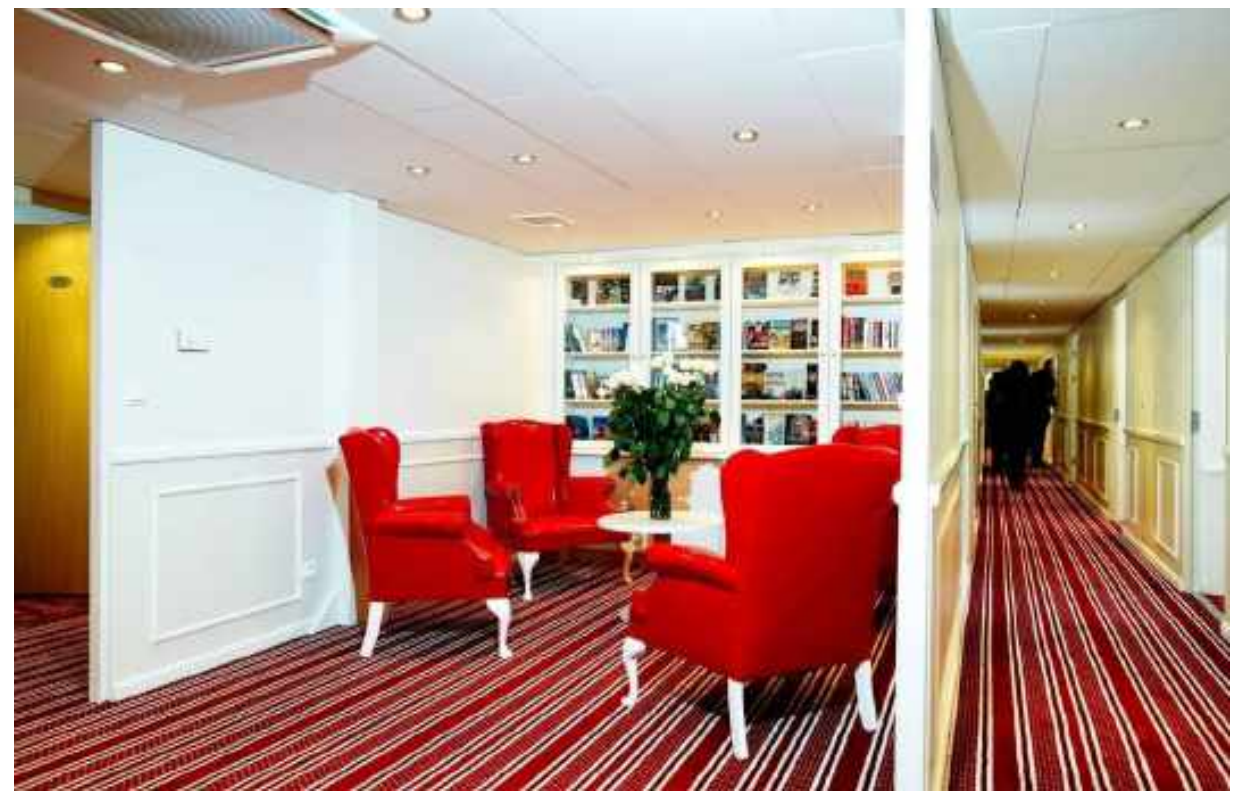

Рис. 9. Новая система кондиционирования с возможностью регулирования температуры в каждой каюте индивидуально 
ВІСНИК

ОДЕСЬКОГО НАЦІОНАЛЬНОГО МОРСЬКОГО УНІВЕРСИТЕТУ № 2 (59), 2019
HERALD

OF THE ODESSA NATIONAL

MARITIME UNIVERSITY № 2 (59), 2019

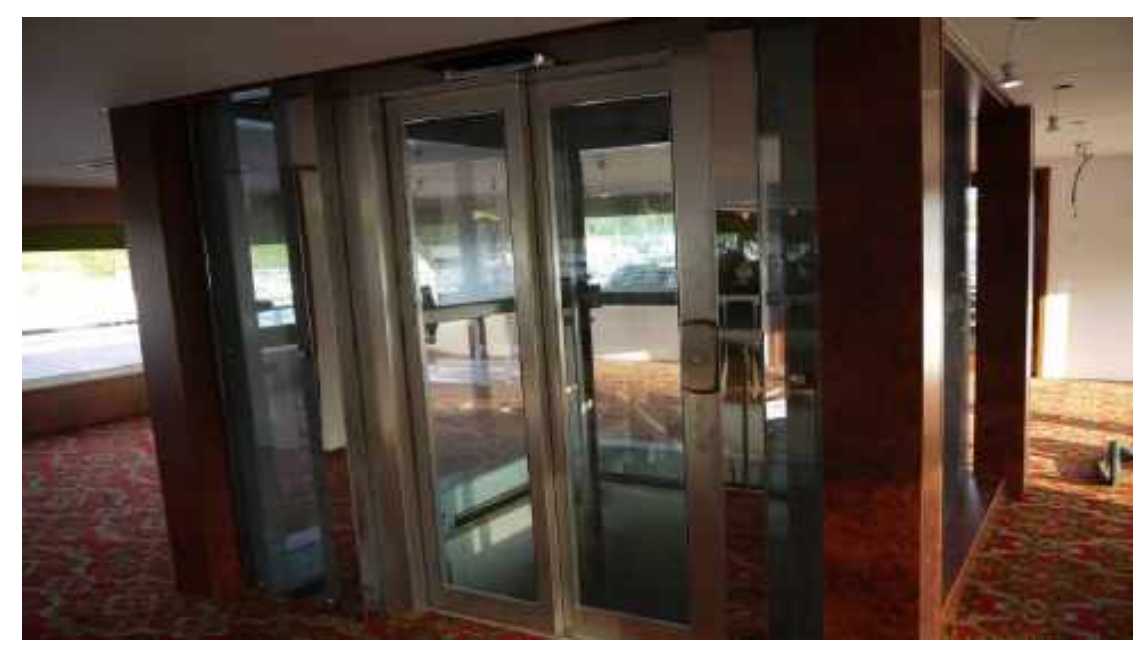

Рис. 10. Лифт, работающий на четырех палубах теплохода

Как только появилась возможность судозаходов морских круизных судов в Санкт-Петербург, особенно после введения 72-часового безвизового въезда в РФ, загрузка речных круизов каждый год падает. Исключением являются только суда, прошедшие полную модернизацию или конверсию. Начиная с 2012 года, судно работает с иностранными туристами на линии Санкт-Петербург-Москва.

«Викинг Синеус» (модернизация РКПС проекта 301). Следующим примером является судно проекта PV17 «Викинг Синеус» (см. рисунок 11) пассажировместимостью 196 человек компании Viking River Cruises (модернизация судна «Михаил Ломоносов»). Работы проводились в межнавигационный период 2013-2014 года с целью увеличения комфортабельности судна за счет значительного увеличения площади кают, ресторанов и общественных помещений.

Первый раз «Викинг Синеус» прибыл в Одессу 12 сентября 2014 года. На борту было 177 пассажиров, в основном граждан Германии. Следующим портом захода этого круиза был порт Галац в Румынии.

Проект PV17 был разработан Морским Инженерным Бюро. Судно предназначалось для перевозки пассажиров на круизных линиях Киев-Херсон-Севастополь-Одесса-Ялта и Киев-Херсон-Одесса-Дунайская Прорва-Бургас (в период с апреля по октябрь).

Класс Регистра Судоходства Украины - + М-ПР 2,5.

Судно представляет собой четырехпалубный трехвинтовой теплоход габаритной длиной 125,0 м, шириной 16,70 м, с четырехярусной надстройкой по всей длине судна, с кормовым расположением машинного отделения, и ходовым мостиком в носовой части, с двойным дном, с наклонным форштевнем и крейсерской кормовой оконечностью. 
ВІСНИК

ОДЕСЬКОГО НАЦІОНАЛЬНОГО

МОРСЬКОГО УНІВЕРСИТЕТУ

№ 2 (59), 2019
HERALD

OF THE ODESSA NATIONAL

MARITIME UNIVERSITY № 2 (59), 2019

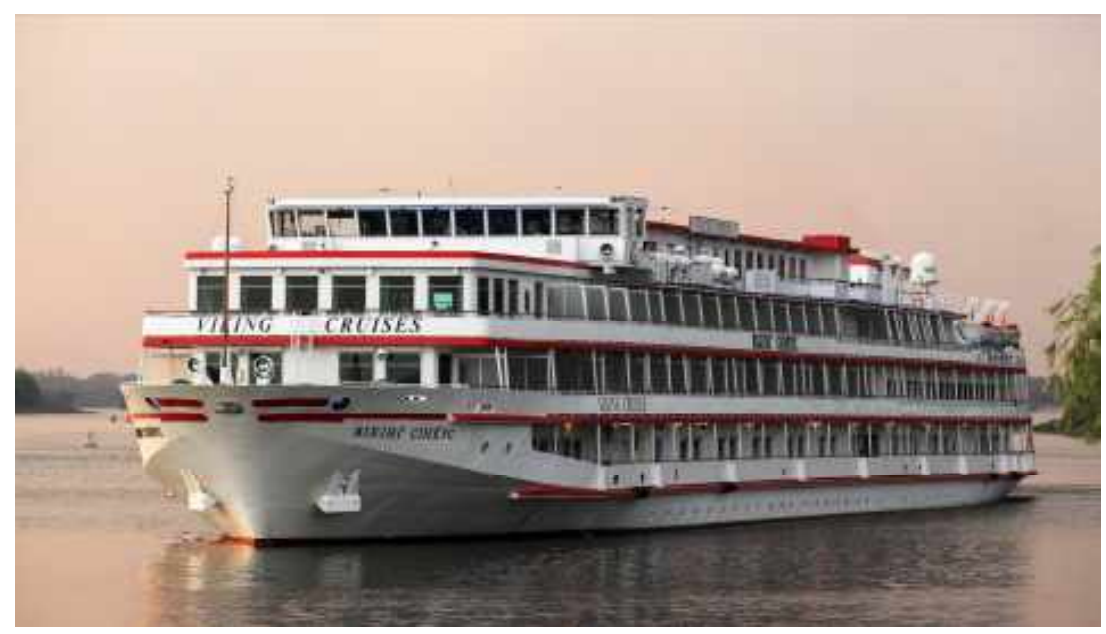

Рис. 11. Общий вид РКПС проекта РV17 Автор фотографии Вадим Фордик [6]

Для размещения 196 пассажиров предусмотрены 98 двухместных кают, включая:

- четыре апартамента с балконом площадью от 30,1 до 31,6 м²;

- две люкс каюты с балконами площадью 24,2 м²;

- шестьдесят кают с балконами площадью от 13,5 до $16,0 \mathrm{~m}^{2}$ (см. рисунок 12);

- тридцать две каюты площадью от 11,1 до 12,9 м².

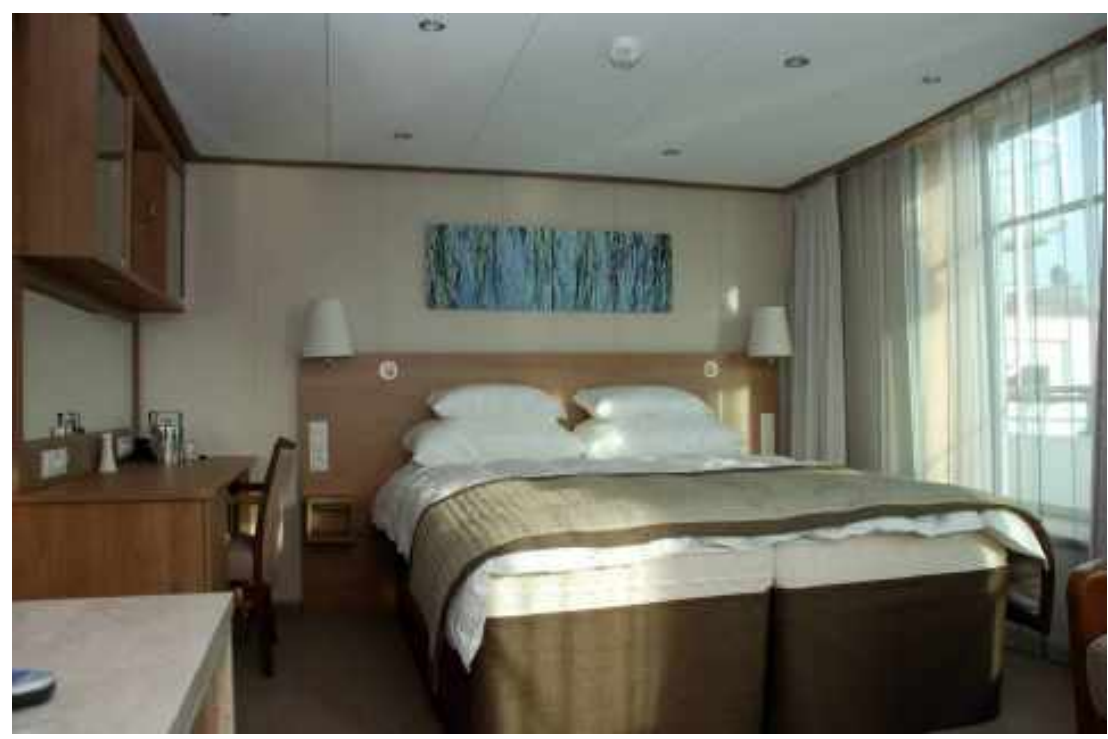

Рис. 12. Стандартная пассажсирская каюта 
ВІСНИК

ОДЕСЬКОГО НАЦІОНАЛЬНОГО

МОРСЬКОГО УНІВЕРСИТЕТУ

№ 2 (59), 2019
HERALD

OF THE ODESSA NATIONAL

MARITIME UNIVERSITY № 2 (59), 2019

Блок пассажирских помещений располагается на трех палубах надстройки: главной, верхней и шлюпочной. Все пассажирские каюты оборудованы двуспальными кроватями, душем с туалетом, кондиционером, шкафами, сейфом, телевизором со спутниковыми и внутрисудовыми каналами, феном, беспроводным Интернетом (Wi-Fi), судовой радиотрансляцией, внутренней и внешней телефонной связью.

Каюты на верхней и шлюпочной палубах имеют индивидуальные балконы. Балконы оборудованы сдвижными перегородками, обеспечивающими свободный проход по палубам вдоль всего судна в аварийных ситуациях.

На верхней палубе расположен ресторан, позволяющий в одну смену кормить всех пассажиров, площадью около $350 \mathrm{~m}^{2}$, вместимостью 212 посадочных мест, перед рестораном организован вместительный вестибюль с кофе станцией, местом отдыха и общественными туалетами.

В носовой части шлюпочной палубы оборудован обзорный бар

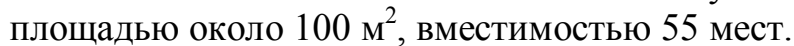

На тентовой палубе разместился музыкальный салон с баром площадью около $150 \mathrm{~m}^{2}$, вместимостью 100 мест и большая открытая палуба с шезлонгами и тентом (см. рисунок 13).

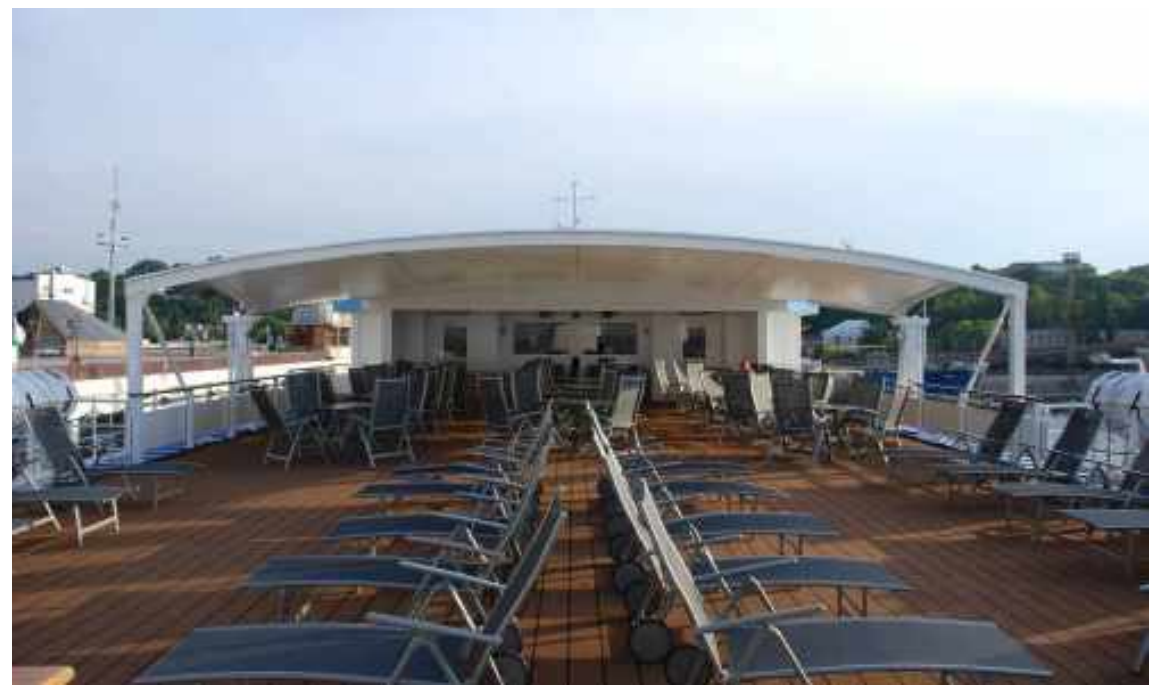

Рис. 13. Холл судна

На главной палубе, в холле (см. рисунок 14) размещена стойка регистрации пассажиров, с зоной отдыха и библиотекой.

Кондиционирование, водоснабжение и вентиляция соответствуют представлениям о гостинице 4*. Пассажирский лифт соединяет все пассажирские палубы теплохода. 


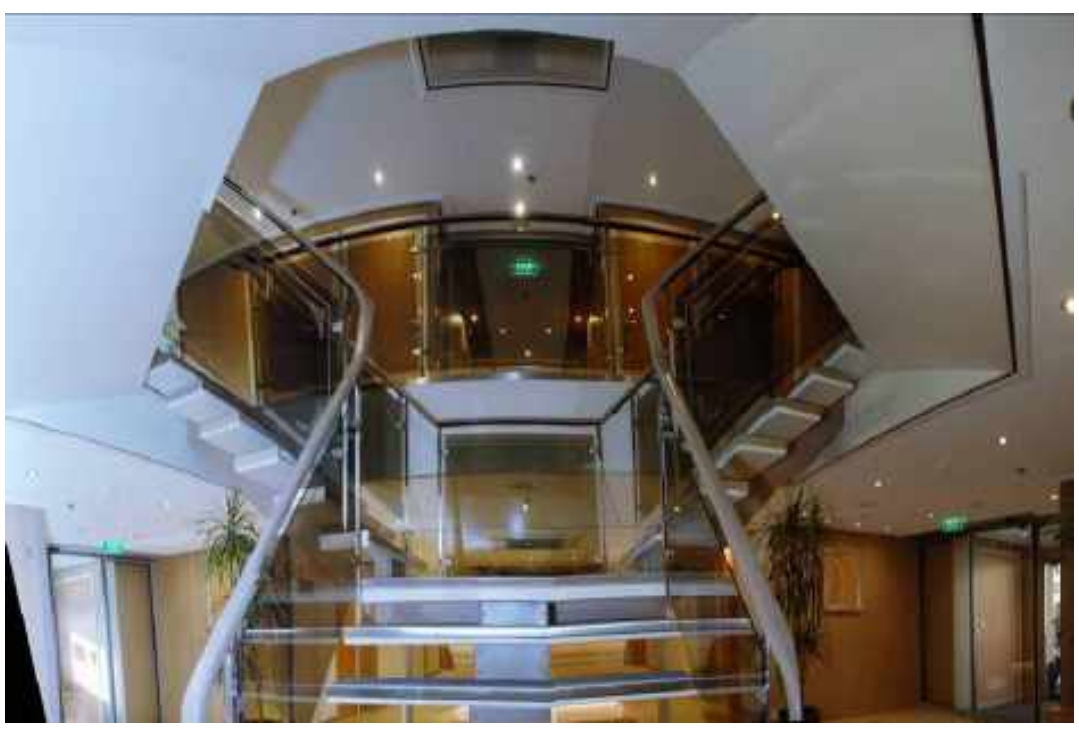

Рис. 14. Холл судна

В качестве главных двигателей используются три среднеоборотных дизеля мощностью 736 кВт каждый. Движение и управляемость судна обеспечивается тремя винтами фиксированного шага диаметром 1800 мм и пятью рулями. Для прохода узкостей и швартовки к причалу на судне установлено носовое подруливающее устройство.

Электростанция состоит из 4 дизель-генераторов по 432 кВт каждый и аварийного дизель-генератора мощностью 100 кВт.

Экипаж и обслуживающий персонал из 84 человек размещается в одно, двух и трехместных каютах на нижней палубе (в корпусе судна) и на тентовой палубе.

Спасательное устройство состоит из четырех спасательных шлюпок и 46 спасательных надувных сбрасываемых плотов.

Судно соответствует повышенным стандартам экологической безопасности. На судне предусмотрена закрытая система сточных и хозяйственно-бытовых вод. Все сточные и хозяйственно-бытовые воды отводятся в сборные цистерны, также на судне имеется установка обработки сточных вод.

«Мстислав Ростропович» (модернизация РКПС проекта 92016). В 2009-2011 годах круизная компания «ВодоходЂ» полностью переоборудовала РКПС «Мстислав Ростропович» проекта 92-016 (см. рисунок 15). Теплоход оснащен современным навигационным оборудованием и развивает скорость до 26 км/ч. Длина судна - 135,7 м, ширина 16,8 м, осадка $-2,9$ м.

Количество посадочных мест - 212. 

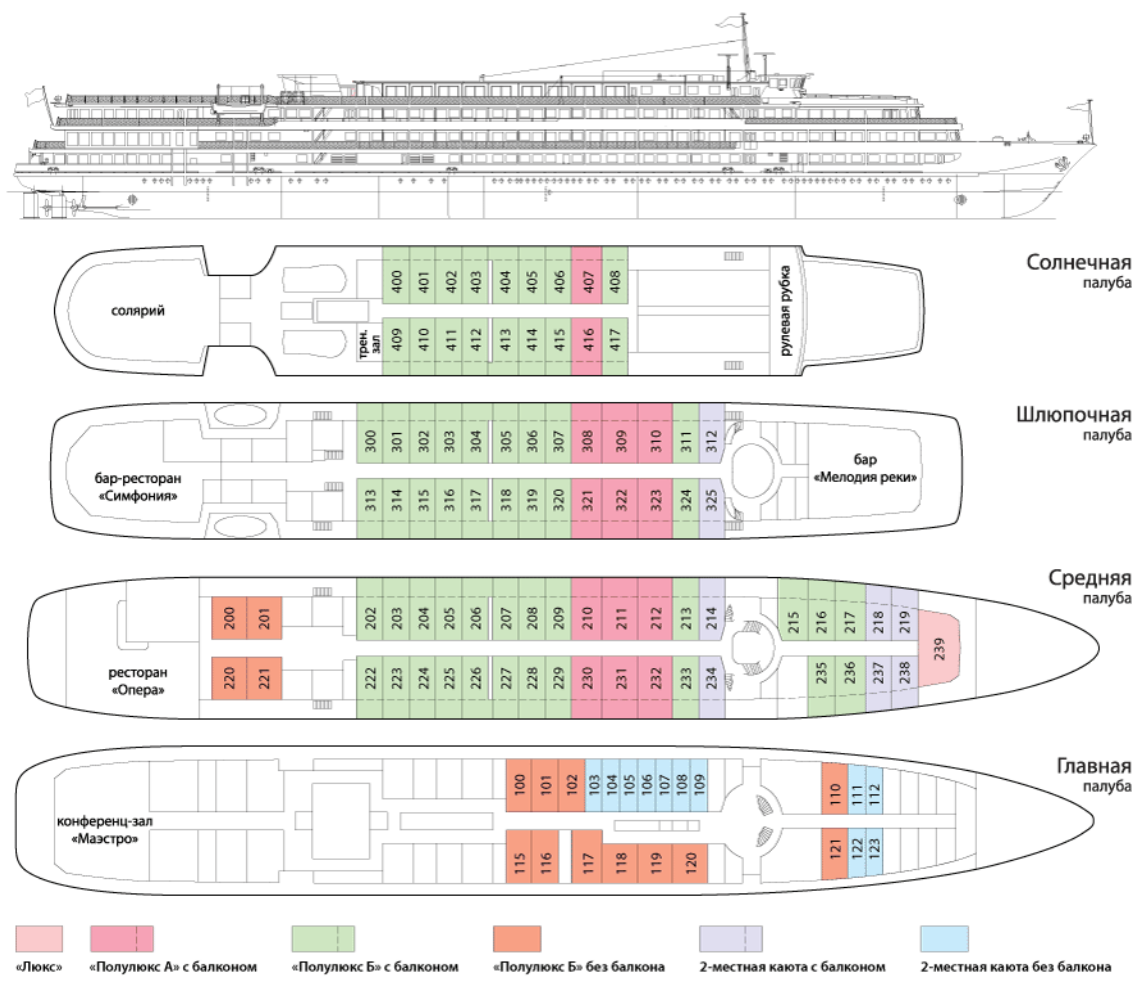

Рис. 15. Т/х «Мстислав Ростропович» после переоборудования

1 каюта класса «Люкс» (см. рисунок 16). Однокомнатная каюта с удобствами (ванна, санузел, кондиционер) рассчитана на размещение до

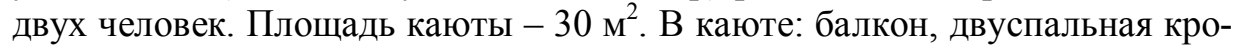
вать, прикроватные тумбы, диван и два кресла, журнальный стол, трюмо, стул, шкаф, телевизор, холодильник, радио, телефон, фен, сейф, электророзетка на $220 \mathrm{~V}$.

14 кают класса «Полулюкс А» с балконом (см. рисунок 17). Однокомнатная каюта с удобствами (душ, санузел, кондиционер) рассчитана

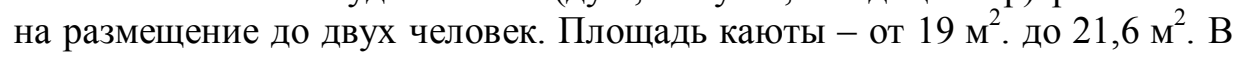
каюте: балкон, две односпальные кровати (можно сдвинуть), прикроватные тумбы, трюмо, стул, шкаф, телевизор, холодильник, радио, телефон, фен, сейф, электророзетка на $220 \mathrm{~V}$.

57 кают класса «Полулюкс Б» с балконом (см. рисунок 18). Однокомнатная каюта с удобствами (душ, санузел, кондиционер) рассчитана на размещение до двух человек. Площадь каюты - от 15,7 м². до 16,5 м². В каюте: балкон, две односпальные кровати (можно сдвинуть), прикроватные тумбы, трюмо, стул, шкаф, телевизор, холодильник, радио, телефон, фен, сейф, электророзетка на $220 \mathrm{~V}$. 


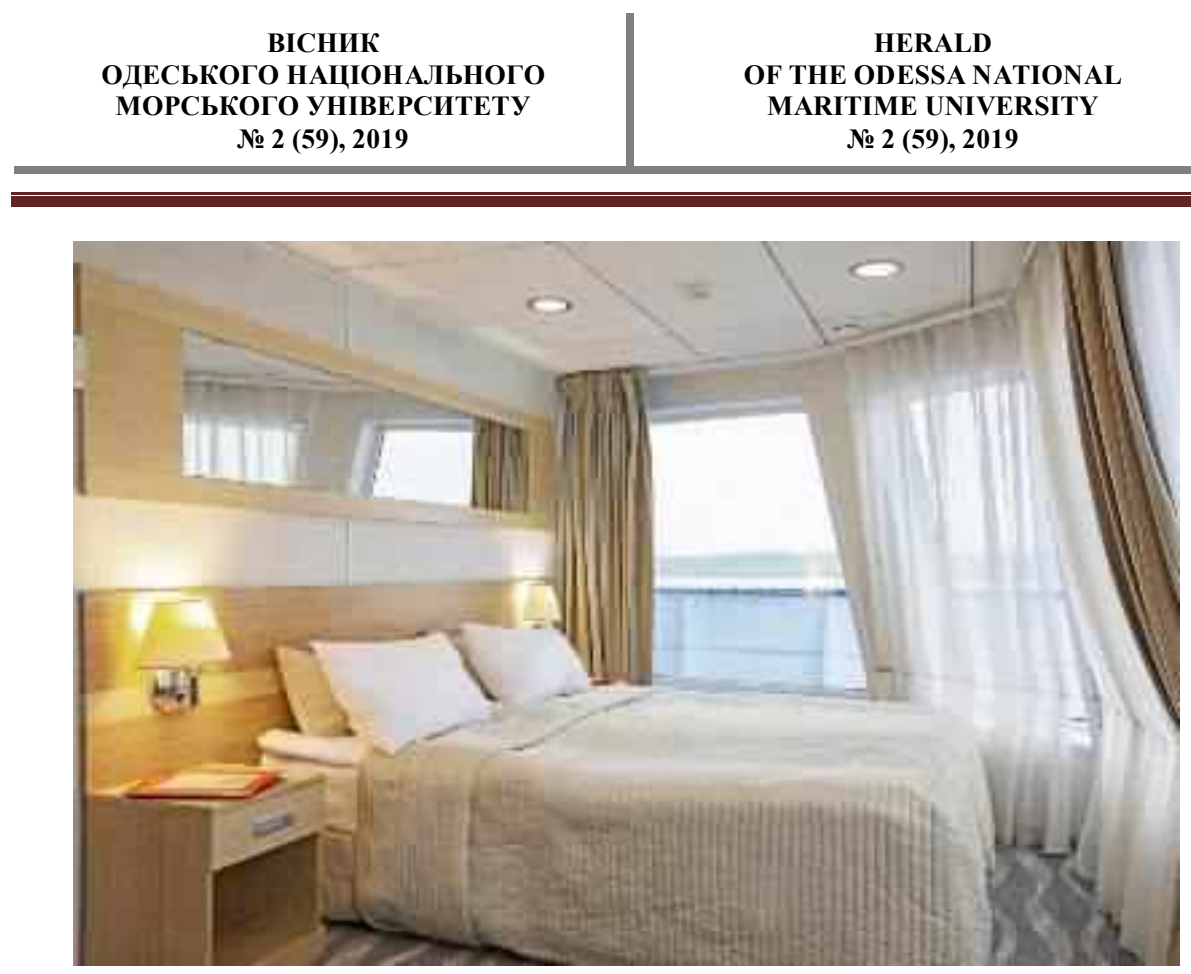

Рис. 16. Каюта класса «Люкс» на $\mathrm{m} / x$ «Мстислав Ростропович»

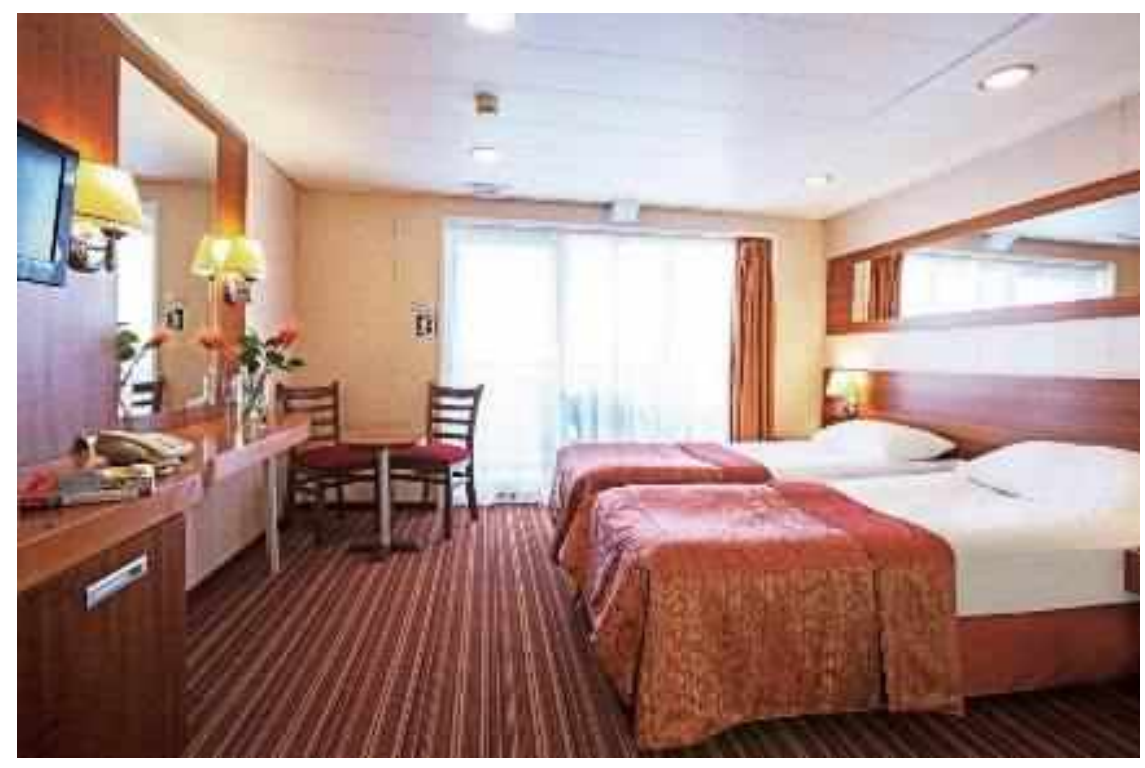

Рис. 17. Каюта класса «Полулюкс А» с балконом на $\mathrm{m} / \mathrm{x}$ «Мстислав Ростропович» 
ВІСНИК

ОДЕСЬКОГО НАЦІОНАЛЬНОГО

МОРСЬКОГО УНІВЕРСИТЕТУ

№ 2 (59), 2019
HERALD

OF THE ODESSA NATIONAL

MARITIME UNIVERSITY № 2 (59), 2019

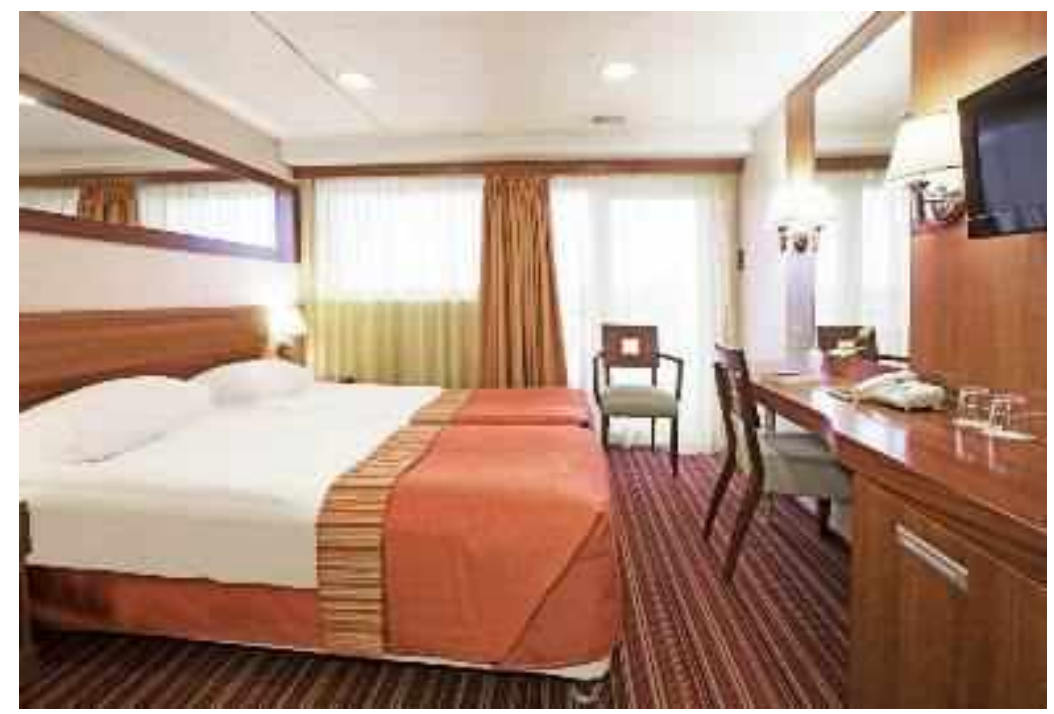

Рис. 18. Каюта класса «Полулюкс Б» с балконом на $\mathrm{m} / \mathrm{x}$ «Мстислав Ростропович»

15 кают класса «Полулюкс Б» без балкона (см. рисунок 19). Однокомнатная каюта с удобствами (душ, санузел, кондиционер) рассчитана на размещение до двух человек. Площадь каюты - от 18,7 м². до 22,6 м². В каюте: две односпальные кровати (можно сдвинуть), прикроватные тумбы, трюмо, стул, шкаф, телевизор, холодильник, радио, телефон, обзорное окно, фен, сейф, электророзетка на $220 \mathrm{~V}$.

8 двухместных одноярусных кают с балконом (см. рисунок 20). Однокомнатная каюта с удобствами (душ, санузел, кондиционер) рассчитана на размещение до двух человек. Площадь каюты - от $12,4 \mathrm{~m}^{2}$. до

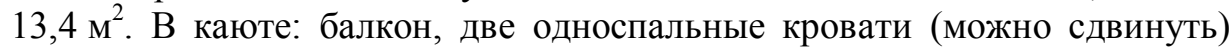
или двуспальная кровать, прикроватные тумбы, трюмо, стул, шкаф, телевизор, холодильник, радио, телефон, фен, сейф, электророзетка на $220 \mathrm{~V}$. В каютах 214 и 234 - две односпальные кровати (можно сдвинуть); в каютах 218, 219, 237, 238 - двуспальная кровать.

11 двухместных одноярусных кают без балкона (см. рисунок 21). Однокомнатная каюта с удобствами (душ, санузел, кондиционер) рассчитана на размещение до двух человек. Площадь каюты - от $10 \mathrm{~m}^{2}$. до $13 \mathrm{~m}^{2}$. В каюте: две односпальные кровати (не сдвигаются) или двуспальная кровать, прикроватные тумбы, трюмо, стул, шкаф, телевизор, холодильник, радио, телефон, обзорное окно, фен, сейф, электророзетка на $220 \mathrm{~V}$. В каютах 103-109 - две односпальные кровати (не сдвигаются); в каютах 111, 112, 122, 123 - двуспальная кровать. 


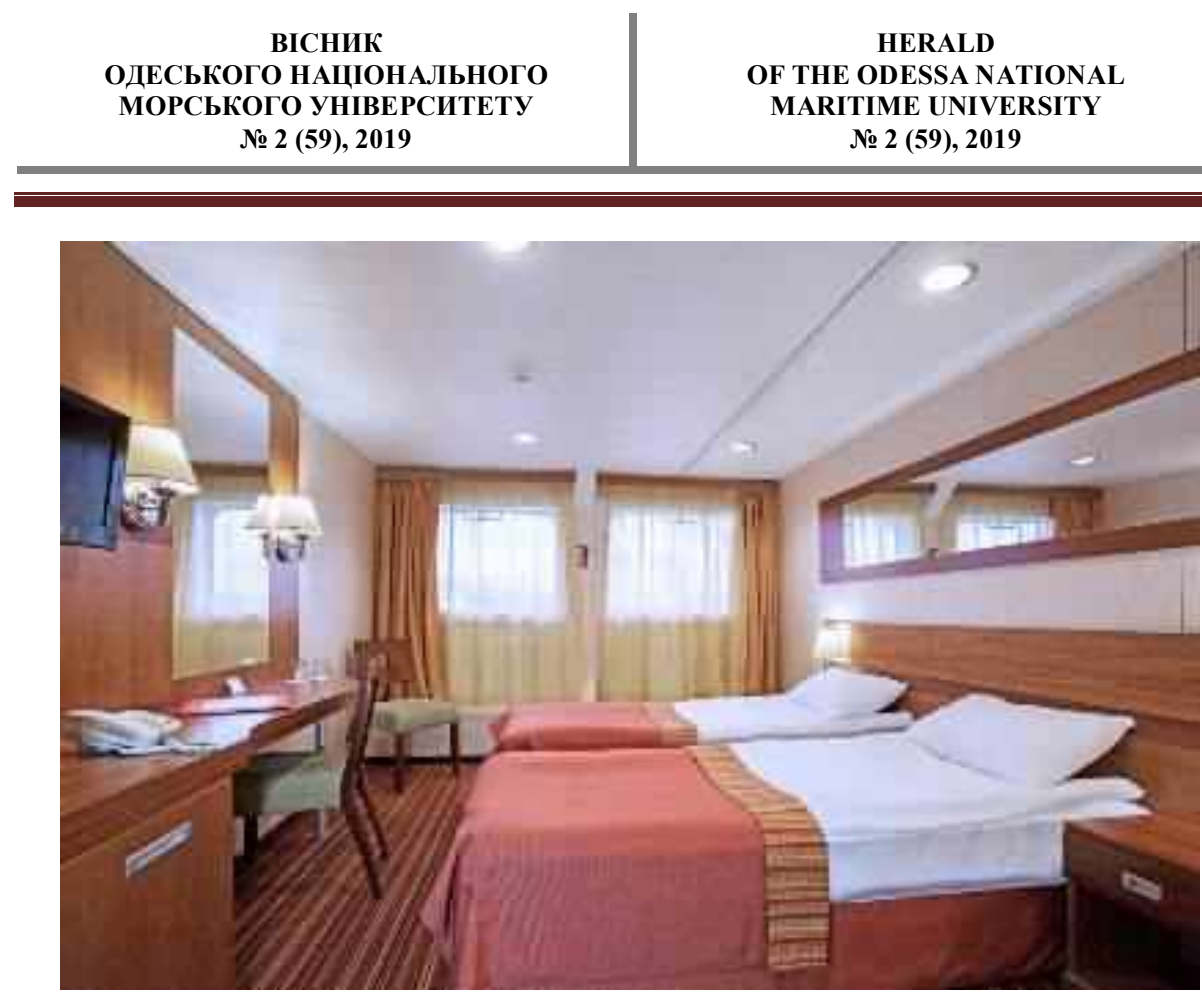

Рис. 19. Каюта класса «Полулюкс Б» без балкона на $\mathrm{m} / \mathrm{x}$ «Мстислав Ростропович»

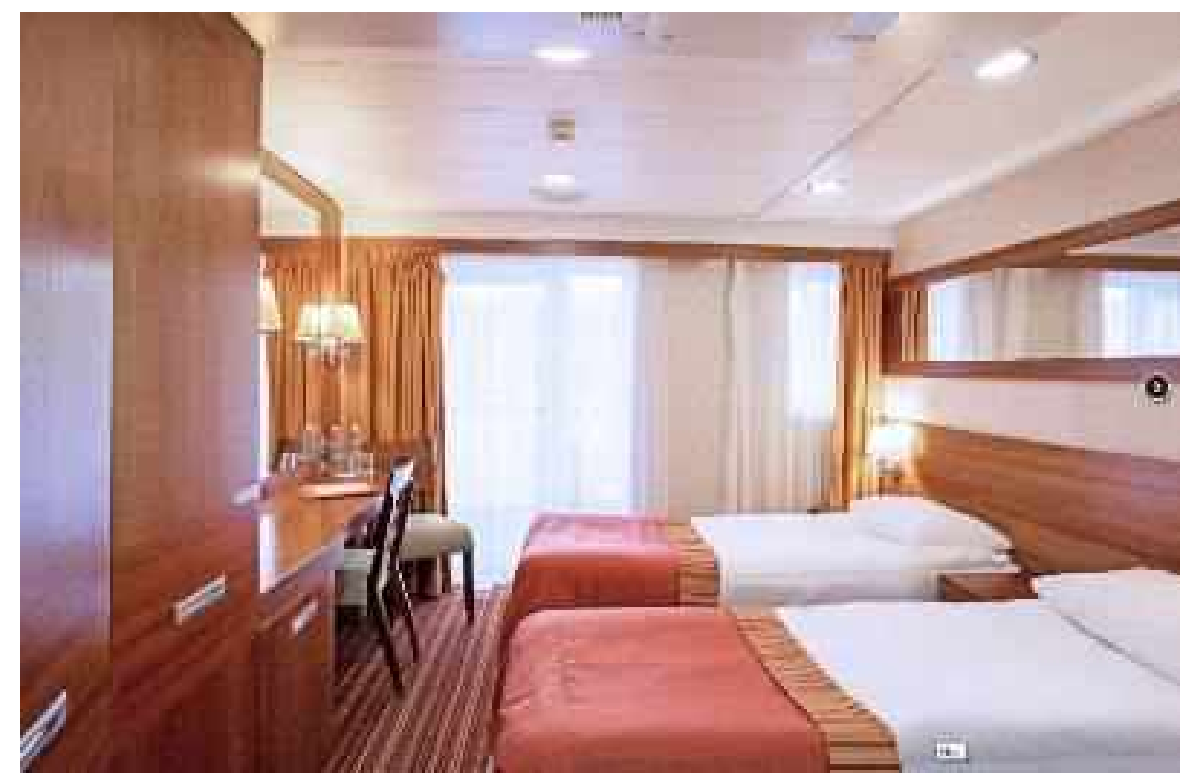

Рис. 20. Двухместная одноярусная каюта с балконом на $\mathrm{m} / \mathrm{x}$ «Мстислав Ростропович» 


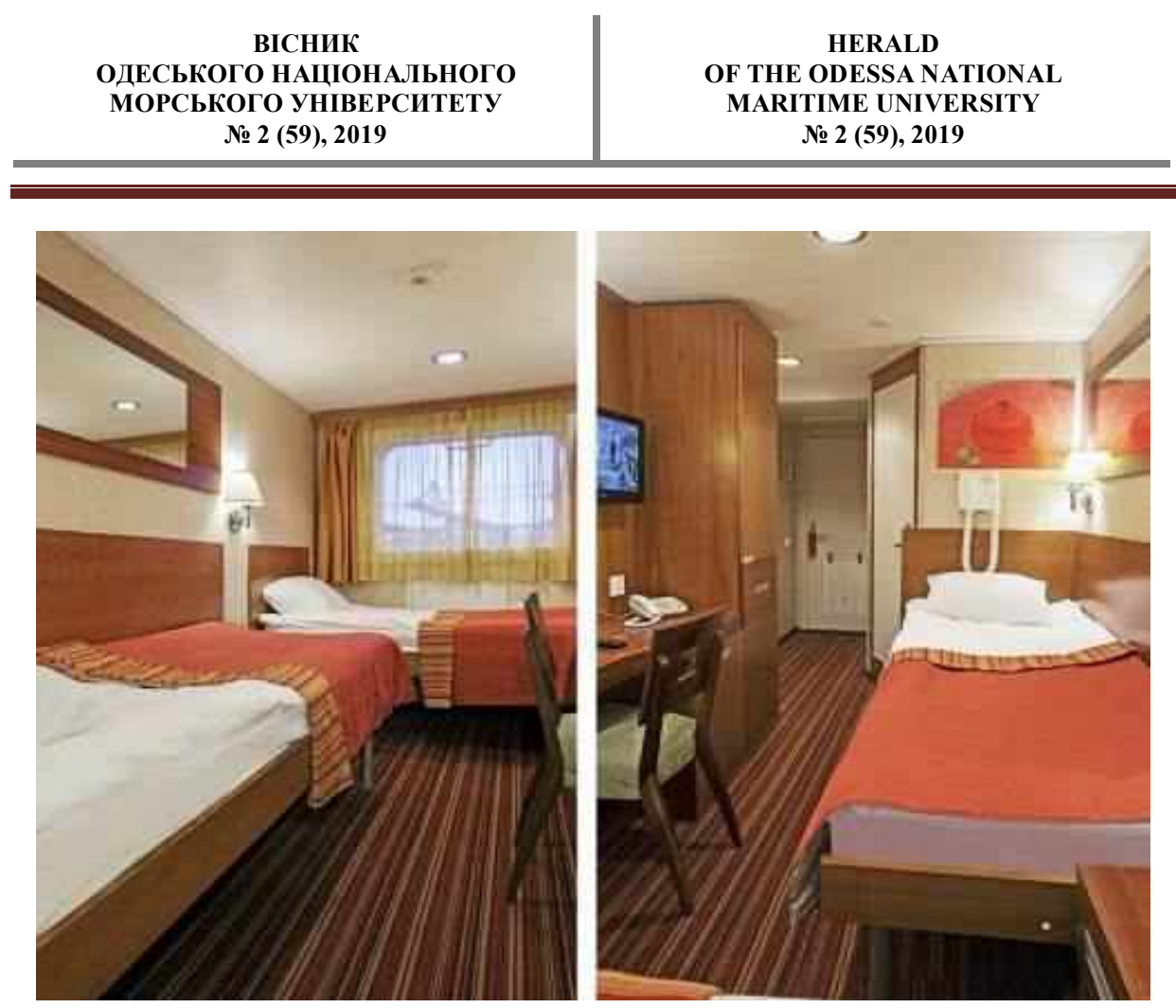

Рис. 21. Двухместная одноярусная каюта без балкона на $\mathrm{m} / \mathrm{x}$ «Мстислав Ростропович»

Во всех каютах: шкаф для одежды, телевизор (спутниковое телевидение), сейф, холодильник, фен, радио, телефон, душ, санузел, обзорное окно или балкон, электророзетка $220 \mathrm{~V}$.

На борту: ресторан, бар-ресторан, бар, конференц-зал, лифт, тренажерный зал, сувенирный киоск, Wi-fi интернет.

«Омега» (конверсия РКПС проекта 588). Более подробно рассмотрим конверсию (строительство нового судна с использованием элементов существующего) судна «Ильич» проекта 588 (см. рисунок 22), а именно, проект PV06.

Судно проекта PV06 строится с использованием ранее эксплуатировавшихся элементов т/х «Ильич» (проект 588) в соответствии с Руководством Р.003-2003 «Строительство судов внутреннего и смешанного плавания с использованием элементов эксплуатировавшихся судов» Российского Речного Регистра. С 2012 года действие Руководства приостановлено в соответствии с требованиями Технического регламента, но т.к. процедура была начата до 2012 года, то судно продолжает строиться. таблице 1 .

Сравнение основных характеристик судов представлено в 
ВІСНИК

ОДЕСЬКОГО НАЦІОНАЛЬНОГО

МОРСЬКОГО УНІВЕРСИТЕТУ

№ 2 (59), 2019
HERALD

OF THE ODESSA NATIONAL

MARITIME UNIVERSITY № 2 (59), 2019

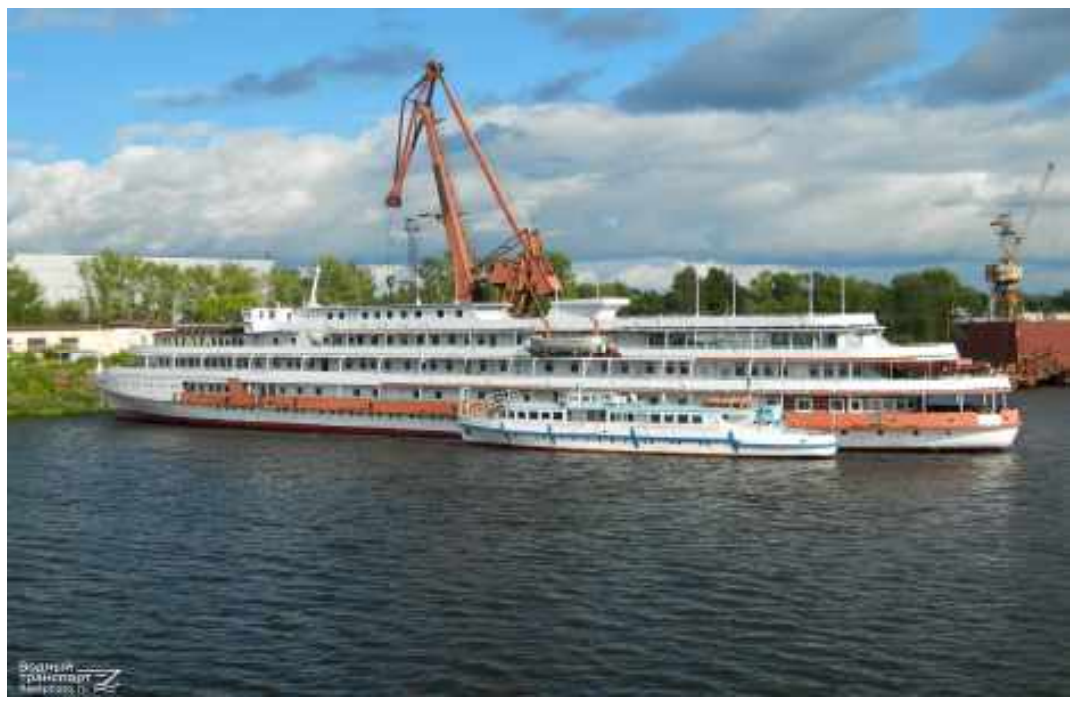

Рис. 22. Конверсия судна «Ильич» по проекту РV06 [7]

Таблица 1

Сравнение основных характеристик судов

\begin{tabular}{|l|c|c|}
\hline \multicolumn{1}{|c|}{ Основные характеристики судна } & «Ильич» & $\begin{array}{c}\text { Проект } \\
\text { PV06 }\end{array}$ \\
\hline Длина по КВЛ, м & 90,0 & 90,0 \\
\hline Ширина габаритная, м & 14,3 & 14,3 \\
\hline Ширина по КВЛ, м & 12,0 & 12,0 \\
\hline Высота борта, м & 4,3 & 4,3 \\
\hline Высота от основной линии без мачты, м & 16,7 & 16,7 \\
\hline Осадка, м & 2,44 & 2,44 \\
\hline Пассажиры / мест, чел. & 364 & 120 \\
\hline Экипаж / мест, чел. & 72 & $70 / 72$ \\
\hline Максимальная длительная мощность ГД, кВт & $3 \times 294$ & $3 \times 331$ \\
\hline Скорость хода в грузу при осадке 2,4 м, узл., около & 12,8 & 12,8 \\
\hline Автономность, суток & 7,5 & 7,5 \\
\hline
\end{tabular}

При проектировании общего расположения форма корпуса осталась без изменения. Надстройка судна была подвергнута значительной модернизации, связанной с увеличением полезной площади и комфортабельности пассажирской зоны. Пассажировместимость была уменьшена с 364 человек до 120 человек.

Распределение площадей палуб проектов PV06 и 588 представлено в таблице 2 . 
ВІСНИК

ОДЕСЬКОГО НАЦІОНАЛЬНОГО МОРСЬКОГО УНІВЕРСИТЕТУ № 2 (59), 2019
HERALD

OF THE ODESSA NATIONAL

MARITIME UNIVERSITY № 2 (59), 2019

Таблица 2

Распределение площңадей палуб проектов РV06 и 588

\begin{tabular}{|l|c|c|c|c|}
\hline \multicolumn{1}{|c|}{ Помещения } & \multicolumn{2}{|c|}{ PV06 } & \multicolumn{2}{c|}{588} \\
\hline Каюты экипажа & 418,3 & $9,1 \%$ & 369 & $8,8 \%$ \\
\hline Пассажирские каюты & 754,7 & $16,4 \%$ & 774,7 & $18,5 \%$ \\
\hline Машинные помещения & 337,5 & $7,3 \%$ & 252,7 & $6,0 \%$ \\
\hline Кладовые & 62,2 & $1,4 \%$ & 97,8 & $2,3 \%$ \\
\hline Коридоры & 330 & $7,2 \%$ & 440,3 & $10,5 \%$ \\
\hline Вспомогательные & 94,7 & $2,1 \%$ & 155,2 & $3,7 \%$ \\
\hline Провизионные кладовые & 62,4 & $1,4 \%$ & 24,8 & $0,6 \%$ \\
\hline Вестибюли & 179,4 & $3,9 \%$ & 89,5 & $2,1 \%$ \\
\hline $\begin{array}{l}\text { Помещения обслуживания } \\
\text { пассажиров }\end{array}$ & 121 & $2,6 \%$ & 18 & $0,4 \%$ \\
\hline $\begin{array}{l}\text { Общественные помещения для } \\
\text { экипажа }\end{array}$ & 46,8 & $1,0 \%$ & 38,6 & $0,9 \%$ \\
\hline Камбуз & 27,8 & $0,6 \%$ & 28,1 & $0,7 \%$ \\
\hline $\begin{array}{l}\text { Провизионные помещения } \\
\text { для экипажа }\end{array}$ & 108,8 & $2,4 \%$ & 73,3 & $1,8 \%$ \\
\hline Салоны & 375,5 & $8,2 \%$ & 262,5 & $6,3 \%$ \\
\hline Посты управления & 61,4 & $1,3 \%$ & 40,4 & $1,0 \%$ \\
\hline Якорно-швартовное устройство & 93,1 & $2,0 \%$ & 92,7 & $2,2 \%$ \\
\hline Палубные галереи & 114,9 & $24,3 \%$ & 883,2 & $21,1 \%$ \\
\hline Прочие & 404,4 & $8,8 \%$ & 546,7 & $13,1 \%$ \\
\hline Суммарная площадь палуб & 4592,9 & $100,0 \%$ & 4187,5 & $100,0 \%$ \\
\hline
\end{tabular}

Как видно из этой таблицы, площадь пассажирских кают практически не изменилась по сравнению с первоначальным проектом, однако, учитывая, что пассажировместимость уменьшилась почти в 3 раза, можно сделать вывод, что удельная площадь пассажирских кают на одного пассажира увеличилась в 3 раза, следовательно, увеличилась комфортабельность теплохода.

Также следует отметить увеличение площадей общественных помещений для пассажиров, что отражает современные тенденции в проектировании круизных судов, направленные на «преобразование судна в плавучий отель $4 *$ » с соответствующими условиями обитания пассажиров.

Общее расположение проекта PV06 приведено на рисунке 23.

Судно имеет 4 палубы, среднее расположение трехъярусной надстройки и одноярусной рубки, 7 водонепроницаемых поперечных переборок, разделяющих судно на 8 водонепроницаемых отсеков. 
ВІСНИК

ОДЕСЬКОГО НАЦІОНАЛЬНОГО

МОРСЬКОГО УНІВЕРСИТЕТУ № 2 (59), 2019
HERALD

OF THE ODESSA NATIONAL

MARITIME UNIVERSITY № 2 (59), 2019

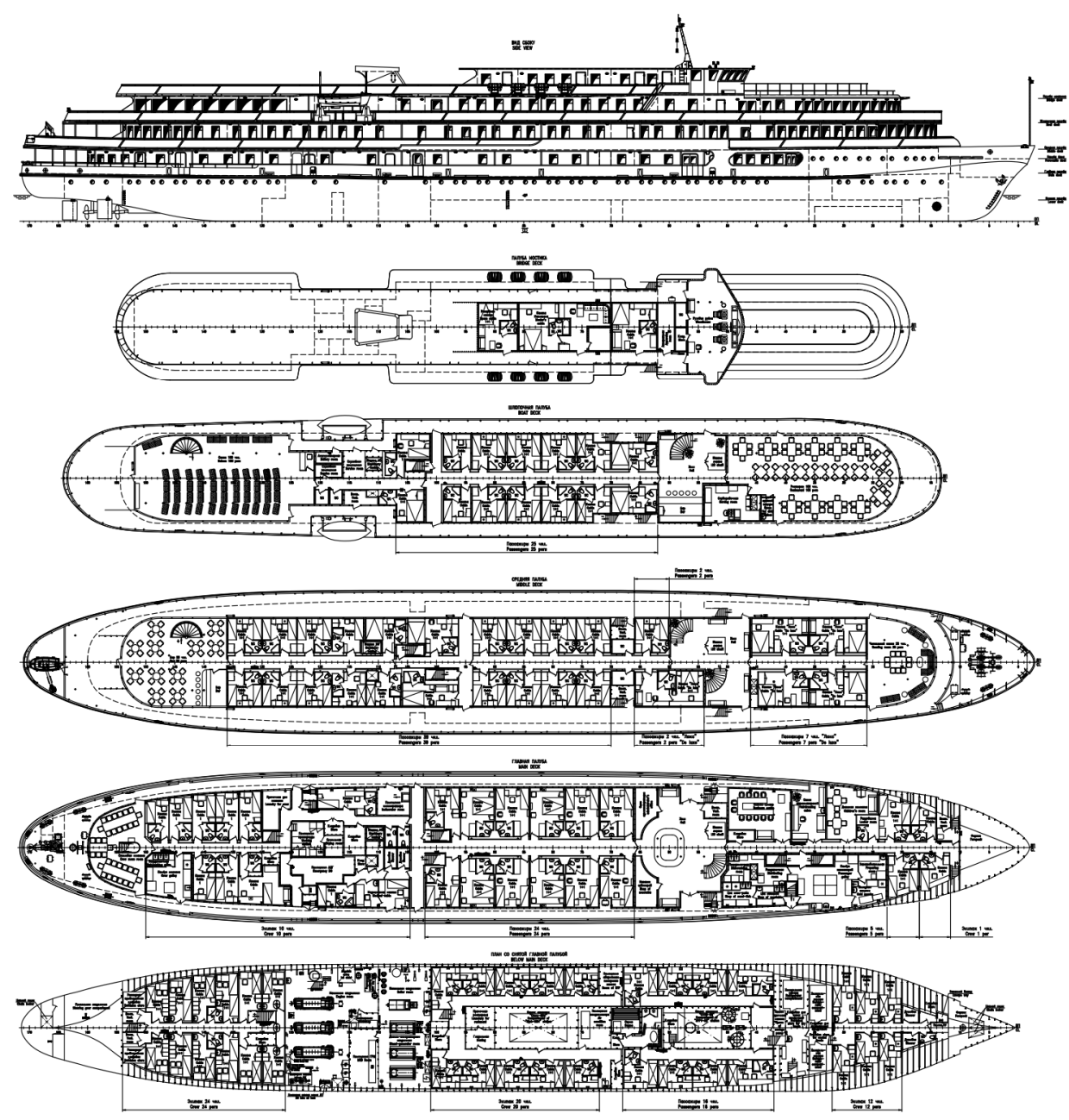

Рис. 23. Общее расположение судна проекта РV06

Жилые и служебные помещения пассажиров и экипажа расположены в трюмных помещения, на трех ярусах надстройки и в рубке.

Пассажиры размещаются в двухместных каютах с индивидуальным санузлом. В каютах предусматривается установка двух одноместных коек либо одной двуспальной койки.

Для размещения пассажиров предназначаются:

- 5 одноместных кают;

- 53 двухместных кают;

- 4 двухместные каюты «люкс»;

- 1 одноместная каюта «люкс». 
ВІСНИК

ОДЕСЬКОГО НАЦІОНАЛЬНОГО

МОРСЬКОГО УНІВЕРСИТЕТУ

№ 2 (59), 2019
HERALD

OF THE ODESSA NATIONAL

MARITIME UNIVERSITY № 2 (59), 2019

Каюты «люкс» включают в себя салон, спальню и индивидуальный санузел.

Каюты первого и второго класса оборудованы индивидуальными санузлами.

В каютах первого класса расположение коек одноярусное, в каютах второго класса - двухъярусное. На судне предусмотрены необходимые санитарно-гигиенические помещения и санитарно-бытовые помещения для пассажиров и камбузный блок.

Общее количество спальных мест для пассажиров на судне - 120 .

Для отдыха пассажиров предусмотрены следующие помещения:

- ресторан на 100 посадочных мест;

- салон для конференций на 100 посадочных мест;

- читальный салон на 25 посадочных мест;

- бар на 50 посадочных мест;

- бизнес-центр;

- парикмахерская;

- детская комната.

Кроме того, на судне имеется магазин сувениров.

Капитан, старший механик и командный состав размещаются в одноместных каютах с индивидуальным санузлом, остальной экипаж и обслуживающий персонал размещается в двух местных каютах.

Для размещения экипажа предназначаются:

- 28 двухместных кают;

- 13 одноместных кают;

- 1 блок-каюта капитана.

Предусмотрена одна запасная двухместная каюта.

Блок-каюта капитана включает в себя кабинет, спальню и индивидуальный санузел.

Каюты комсостава оборудованы индивидуальным санузлом.

Каюты экипажа оборудованы умывальниками.

На судне предусмотрены необходимые санитарно-гигиенические помещения и санитарно-бытовые помещения для экипажа и камбузный блок.

Общее количество мест для экипажа на судне -72 .

Все жилые и общественные помещения, рулевая рубка оборудуются системой кондиционирования.

В каютах пассажиров предусмотрена возможность регулирования температуры воздуха.

Противопожарная защита судна выполнена в соответствии с требованиями Правил РРР. Противопожарная защита обеспечивается конструктивными элементами корпуса и надстройки, системами пожаротушения, стационарной системой обнаружения пожара, материалами противопожарной изоляции, а также комплектом противопожарного снабжения. 
На судне выполнены все необходимые мероприятия для обеспечения выполнения требований Правил Экологической Безопасности судов РРР. Конструкции нового корпуса полностью удовлетворяют требованиям Правил РРР.

Судно спроектировано на срок эксплуатации 15 лет, в соответствии с требованиями Руководства.

Корпус судна делится поперечными водонепроницаемыми переборками на 8 отсеков. В качестве материала основных конструкций корпуса применяется судостроительная сталь категории В и А пределом текучести 235 МПа. Элементы конструкций главной и средней палуб, надстройки до средней палубы выполняются из стали категории В с пределом текучести 235 МПа. Наружная обшивка и примыкающий набор выполняются из стали категории В с пределом текучести 235 МПа. Поперечные переборки выполняются из стали категории А с пределом текучести 235 МПа. Элементы конструкций палуб, надстроек и рубок выше средней палубы выполняются из алюминиевого сплава АМг 5М. Наружный борт, палубы надстроек, надстройки и рубка по всей длине судна выполнены по поперечной системе набора. Главная и средняя палубы выполнены по продольной системе набора. Наружные и внутренние стенки надстроек и рубок выполнены гладкими, наборной конструкции. Поперечная шпация - 550 мм; флоры расположены на каждой шпации.

На судне устанавливаются семь главных водонепроницаемых поперечных переборок, разделяющих корпус на восемь непроницаемых отсеков.

В основном винто-рулевой комплекс остается с исходного судна. Судно дооборудуется вспомогательным электрическим приводом рулевой машины.

Существующее на судне подруливающее устройство (ПУ) демонтируется за исключением бортовых труб и решеток, к которым монтируется новое ПУ мощностью 75 кВт.

В основном якорное устройство остается с исходного судна. Носовое якорное устройство (брашпиль) дооборудуется гидравлическим устройством дистанционной отдачи левого якоря.

На судно устанавливаются три лифта. Один пассажирский лифт на главной палубе с тремя остановками и два грузовых камбузных лифта.

Судно оборудуется новыми главными двигателями и дизельгенераторами необходимой мощности.

Частота вращения гребных винтов - 290 об/мин, мощность каждого ГД - 331 кВт.

На судне устанавливаются компас магнитный основной с дистанционной передачей данных в рулевую рубку; компас магнитный запасной (взаимозаменяемый с основным); две РЛС 9ГГц; приемник GPS; лаг; эхолот; оборудование АИС; картплоттер; гирокомпас; метеостанция. 
ВІСНИК

ОДЕСЬКОГО НАЦІОНАЛЬНОГО

МОРСЬКОГО УНІВЕРСИТЕТУ

№ 2 (59), 2019
HERALD

OF THE ODESSA NATIONAL

MARITIME UNIVERSITY № 2 (59), 2019

На рисунке 24 представлены схемы демонтируемых и устанавливаемых конструкций судна проекта PV06 (боковой вид).

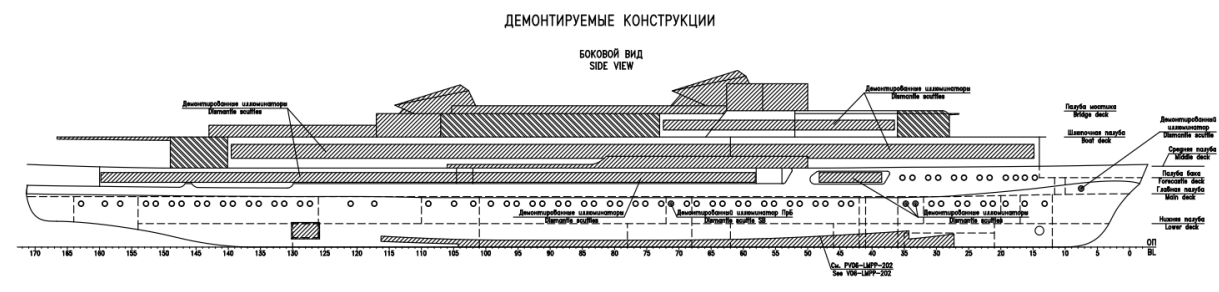

УСТАНАВЛИВАЕМЫЕ КОНСТРУКЦИИ

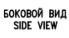

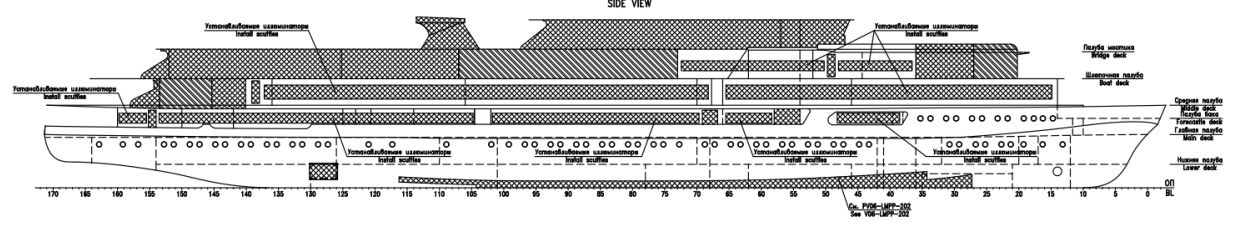

Рис. 24. Схема демонтируемых и устанавливаемых конструкичий на конверсионном РКПС проекта РV06

Основные позиции модернизации:

- приведение судна к современным требованиям Регистра;

- повышение комфортабельности теплохода за счет уменьшения числа кают и изменения компоновки общественных помещений;

- обновление конструкций корпуса;

- обновление основных механизмов (главный двигатель, электростанция, подруливающее устройство).

«Александр Грин» (конверсия проекта Q-065). В 2011 году в компании «Московский туристический флот» возникла идея постройки нового круизного судна на базе существующего. Результатом этой идеи стало создание РКПС проекта PV08 «Александр Грин», построенного с использованием отдельных элементов эксплуатировавшегося судна «Александр Блок». Проект судна PV08 был выполнен Морским инженерным бюро [5].

Судно «Александр Грин» было построено в Рыбинске на Верфи братьев Нобель в 2011-2012 годах, сдано в эксплуатацию 9 июня 2012 года (см. рисунок 25).

«Александр Грин» проекта PV08 стал первым отечественным РКПС, созданным на постсоветском пространстве после 1959 года.

РКПС «Александр Грин» построено в рамках закона о поддержке отечественного судостроения и судоходства, направленного на предоставление льгот операторам рынка, участвующих в новом судостроении и регистрирующих суда под государственным флагом Российской Федерации. Судно зарегистрировано в международном Российском Реестре. 
ВІСНИК

ОДЕСЬКОГО НАЦІОНАЛЬНОГО

МОРСЬКОГО УНІВЕРСИТЕТУ

№ 2 (59), 2019
HERALD

OF THE ODESSA NATIONAL

MARITIME UNIVERSITY № 2 (59), 2019

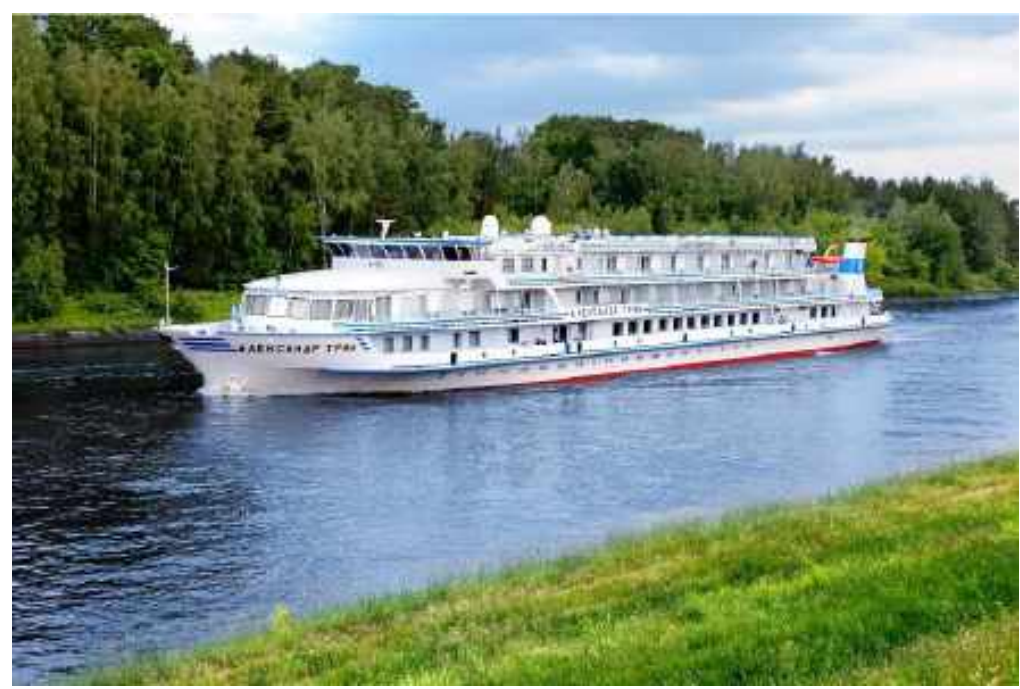

Рис. 25. Конверсированный «Александр Грин» в рейсе [8]

«Московское речное пароходство» осуществило реализацию этого проекта по принципиально новой для судостроения схеме финансирования, с привлечением лизинговой компании «Гознак - лизинг».

РКПС «Александр Грин» зафрахтовано австралийской компанией Scenic Tours и совершает круизы с иностранными туристами. Судно перевозит австралийских туристов, для которых круиз по рекам России входит в общее путешествие от Франции до Японии.

Общее расположение нового теплохода представлено на рисунке 26. «Александр Грин» также позиционируется как 4* отель.

Представляет собой трехпалубный трехвинтовой теплоход габаритной длиной 90,4 м, шириной 14,76 м, с трехъярусной надстройкой по всей длине судна (высота до верхней кромки несъемных частей при осадке 1,6 м составляет 10,4 м), с кормовым расположением машинного отделения и ходовым мостиком в носовой части, с двойным дном, с наклонным форштевнем и транцевой кормовой оконечностью.

Судно предназначено для перевозки круизных пассажиров на внутренних водных путях Европейской части Российской Федерации в бассейнах разряда «М», включая Ладожское и Онежское озера, а также на участках рек с ограниченными габаритами судового хода.

Основное назначение проекта - комфортабельные круизы между Москвой и Санкт-Петербургом с навигационным периодом длительностью 5 месяцев с середины мая до середины октября.

Для размещения 112 пассажиров предусмотрены 56 стандартных двухместных кают площадью 14,5-18 м $^{2}$ (см. рисунок 27) и 6 улучшенных кают «Люкс» площадью 23-25 м² - 4 каюты класса «Люкс» и 2 каюты класса «Панорама Люкс» (см. рисунки 28 и 29). 
ВІСНИК

ОДЕСЬКОГО НАЦІОНАЛЬНОГО

МОРСЬКОГО УНІВЕРСИТЕТУ

№ 2 (59), 2019
HERALD

OF THE ODESSA NATIONAL

MARITIME UNIVERSITY

№ 2 (59), 2019

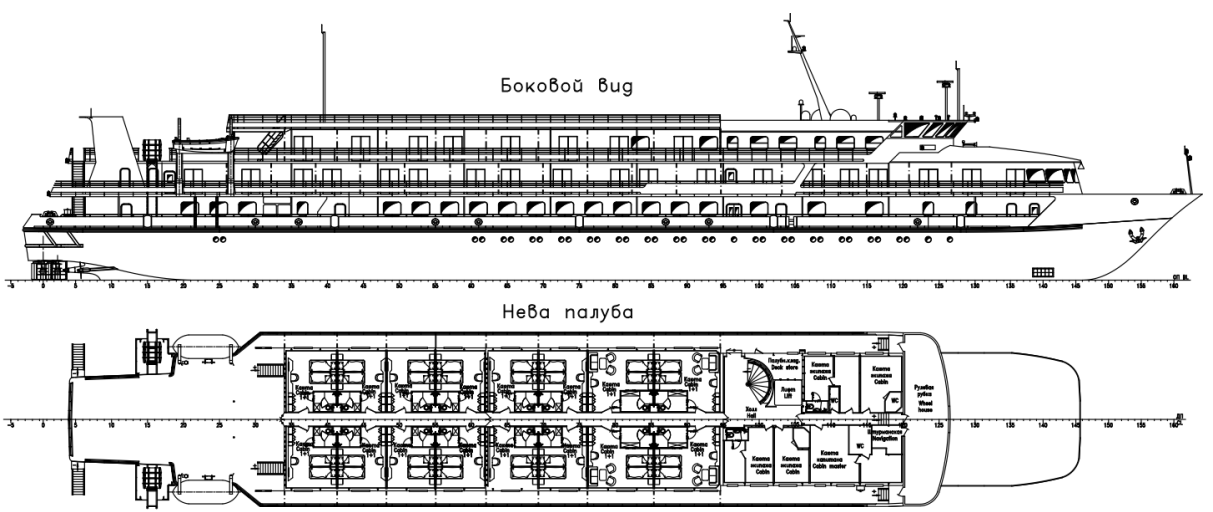

Волаа палуба

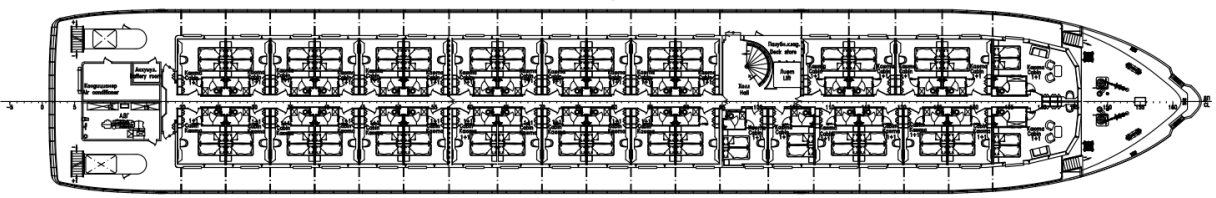

МоскВа палуба

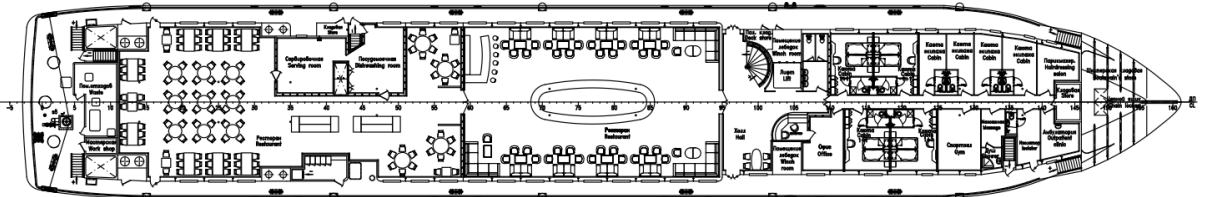

Рис. 26. Общее расположение $m / x$ «Александр Грин»

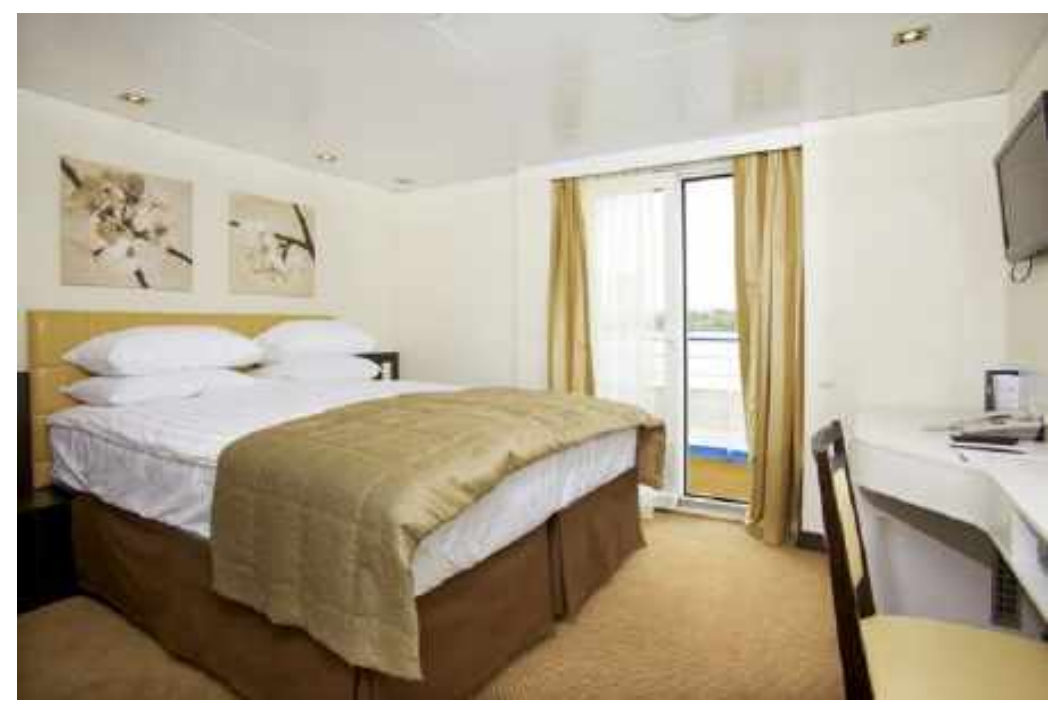

Рис. 27. Общий вид стандартной кають 
ВІСНИК

ОДЕСЬКОГО НАЦІОНАЛЬНОГО

МОРСЬКОГО УНІВЕРСИТЕТУ

№ 2 (59), 2019
HERALD

OF THE ODESSA NATIONAL

MARITIME UNIVERSITY № 2 (59), 2019

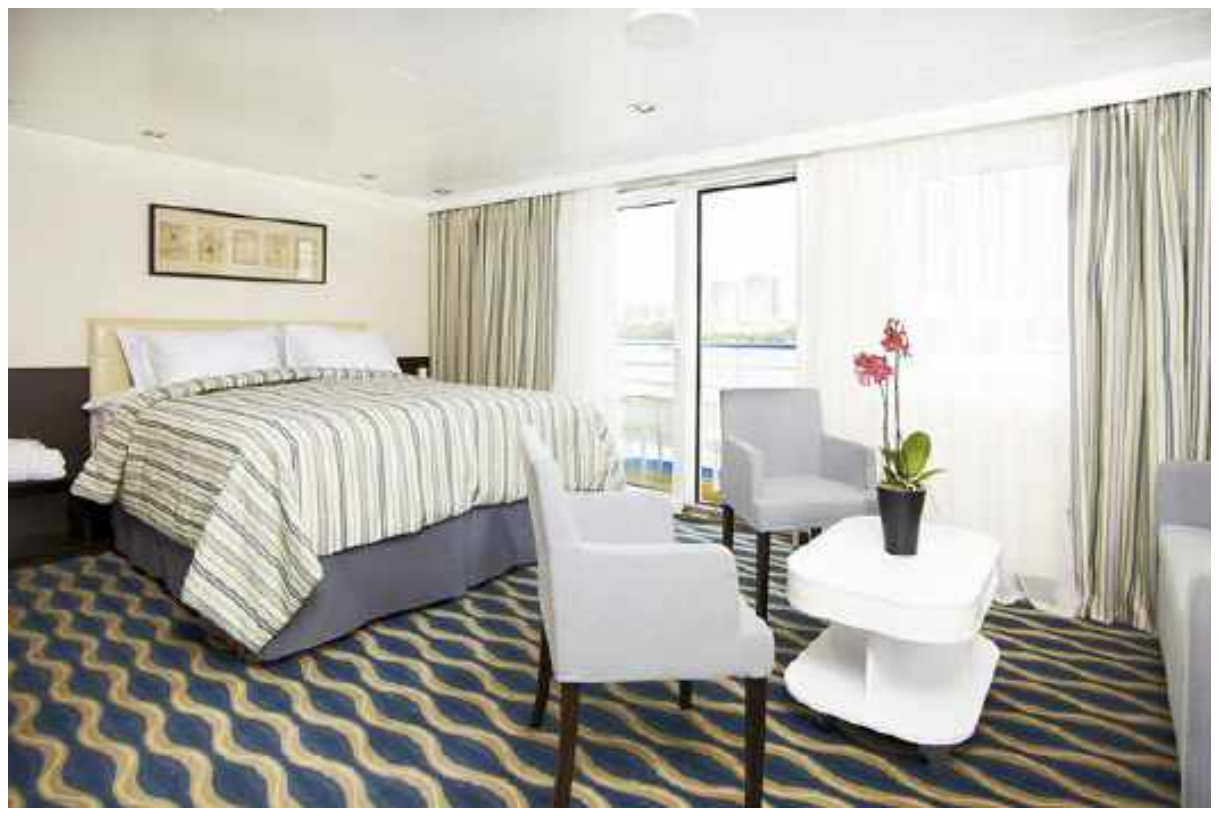

Рис. 28. Общий вид каютье «Люкс» [9]

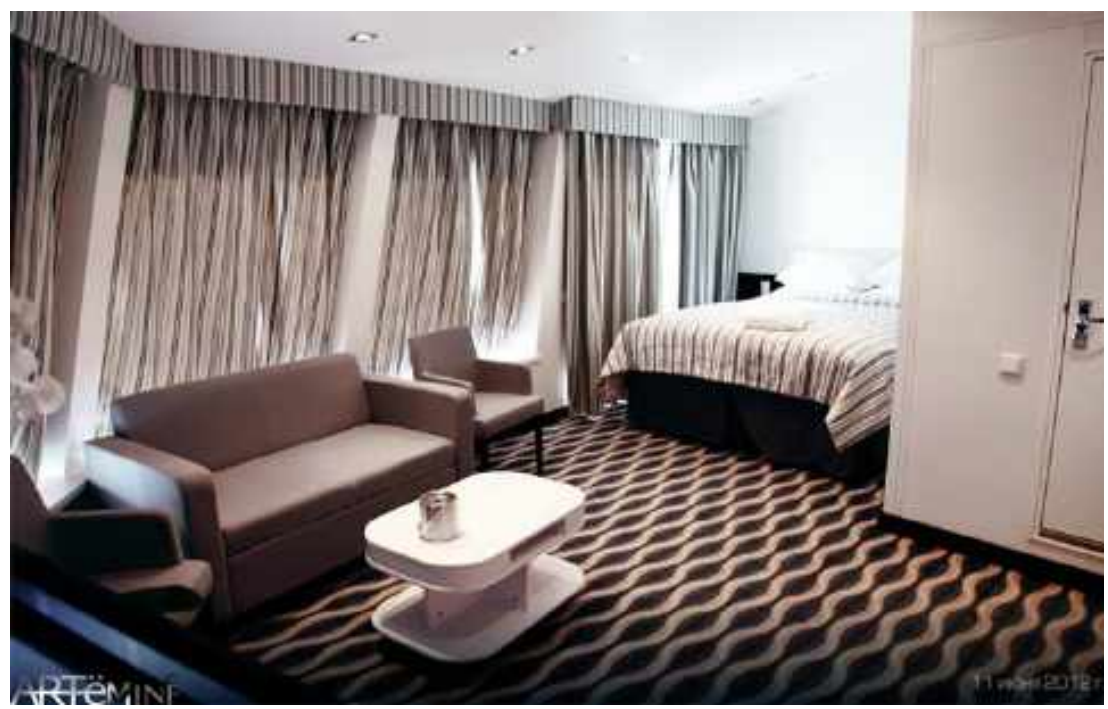

Рис. 29. Общий вид каюты «Панорама Люкс [10]

Блок пассажирских помещений располагается на трех палубах надстройки: главной «Москва», средней «Волга» и шлюпочной «Нева».

Все пассажирские каюты оборудованы двуспальными кроватями, душем с туалетом, кондиционером, шкафами, сейфом, телевизором со 
спутниковыми и внутрисудовыми каналами, феном, электрическими розетками на $220 \mathrm{~V}$, беспроводным Интернетом (Wi-Fi), судовой радиотрансляцией, внутренней и внешней телефонной связью.

Каюты на палубах «Нева» и «Волга» имеют индивидуальные балконы. Балконы оборудованы сдвижными перегородками, обеспечивающими свободный проход по палубам вдоль всего судна в аварийных ситуациях (см. рисунок 30).

К услугам пассажиров на палубе «Москва» ресторан площадью $281 \mathrm{~m}^{2}$ на 150 посадочных мест (см. рисунок 31), салон с баром на 65 мест площадью 221 м² (см. рисунок 32), спортзал, массажная, парикмахерская, амбулатория.

Кондиционирование, водоснабжение и вентиляция также соответствуют представлениям о гостинице $4 *$. Пассажирский лифт соединяет все палубы теплохода (см. рисунок 33).

Большая верхняя открытая палуба с шезлонгами служит для полноценного отдыха туристов (см. рисунок 34).

Новые современные двигатели и оборудование, средства радионавигации, управления и автоматизации обеспечивают безопасную эксплуатацию судна в любых режимах, включая круизы по Ладожскому и Онежскому озерам (см. рисунок 35).

Судно на ходовых испытаниях показало скорость 22 км/час.

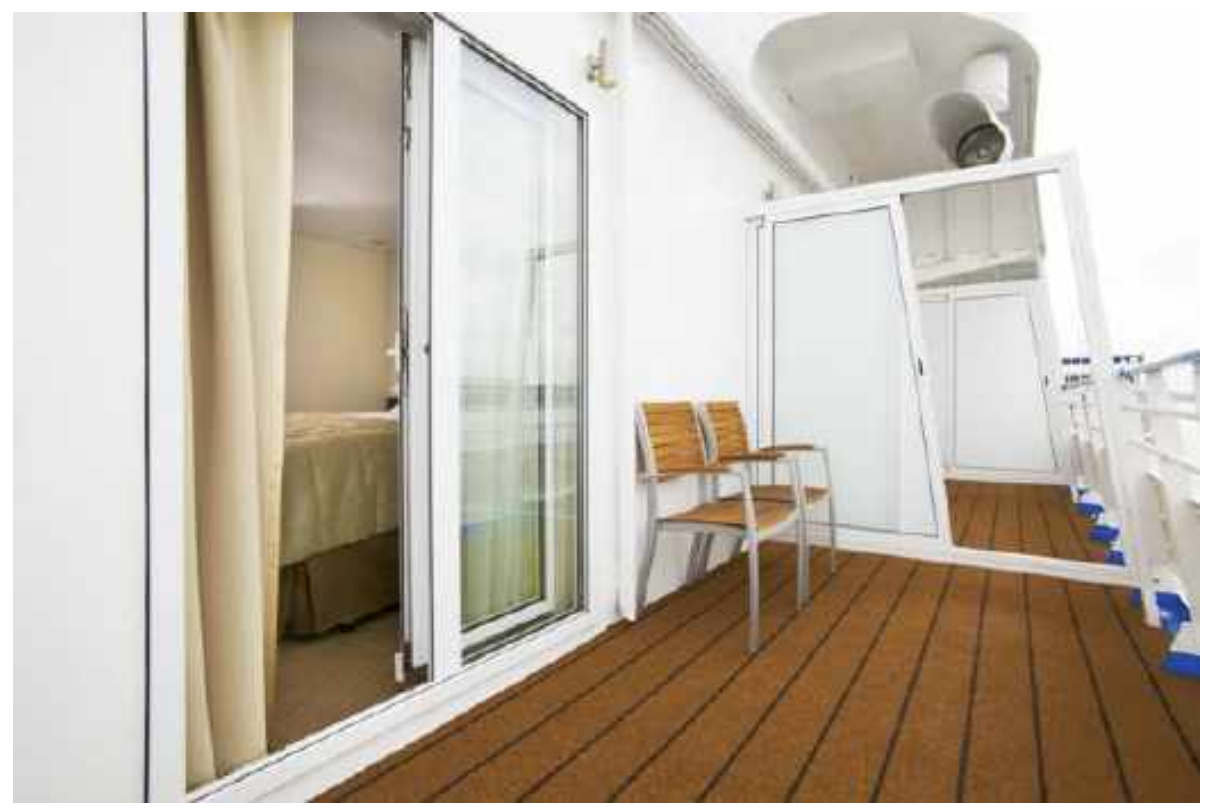

Рис. 30. Вид на балкон 
ВІСНИК

ОДЕСЬКОГО НАЦІОНАЛЬНОГО

МОРСЬКОГО УНІВЕРСИТЕТУ

№ 2 (59), 2019
HERALD

OF THE ODESSA NATIONAL

MARITIME UNIVERSITY

№ 2 (59), 2019

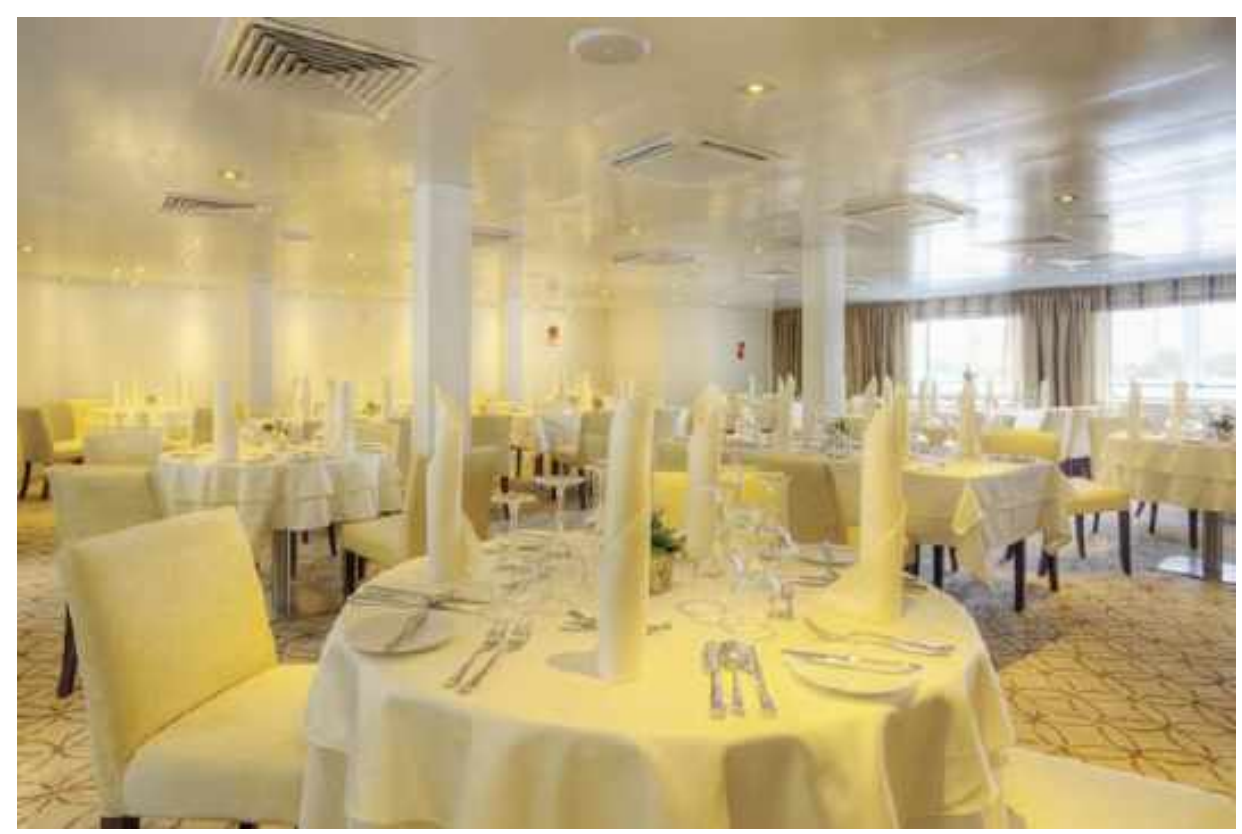

Рис. 31. Ресторан на $m / x$ «Александр Грин»

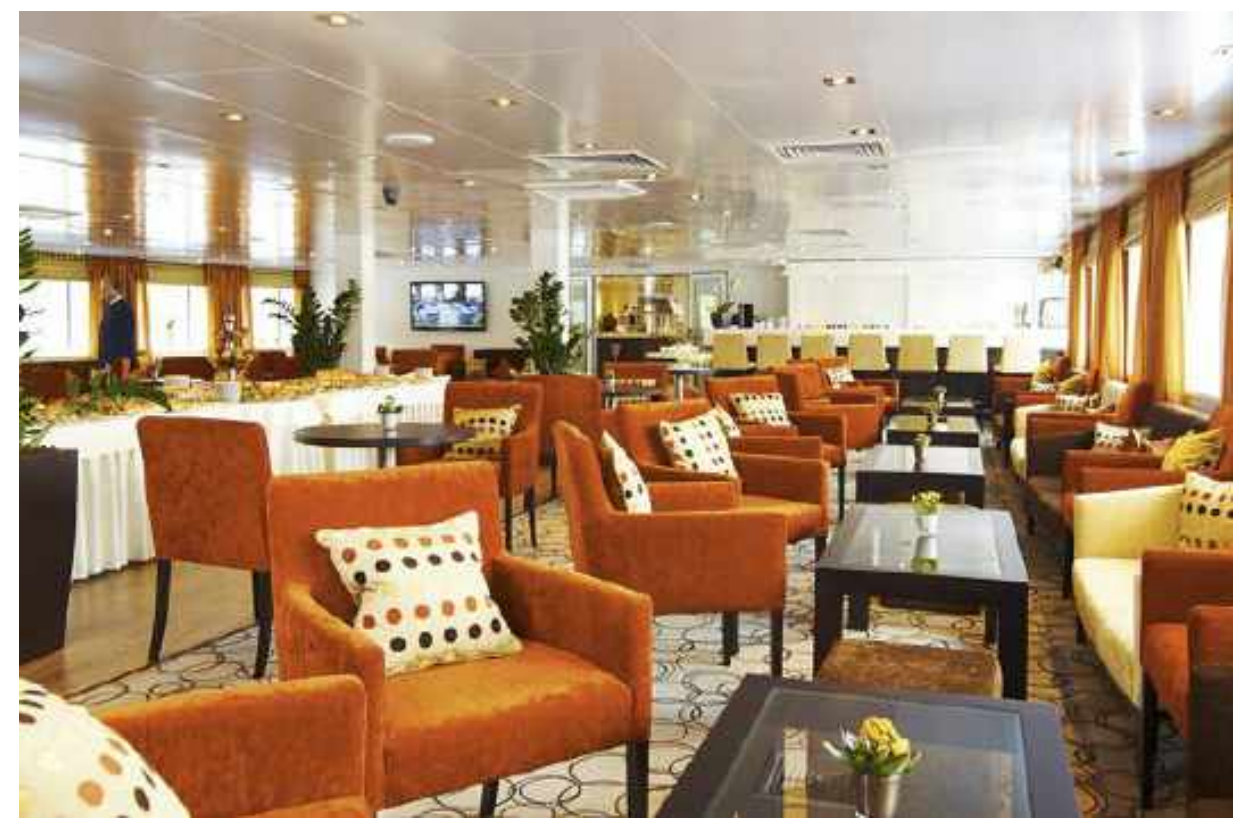

Рис. 32. Бар на $m / x$ «Александр Грин» [11] 
ВІСНИК

ОДЕСЬКОГО НАЦІОНАЛЬНОГО

МОРСЬКОГО УНІВЕРСИТЕТУ

№ 2 (59), 2019
HERALD

OF THE ODESSA NATIONAL

MARITIME UNIVERSITY № 2 (59), 2019

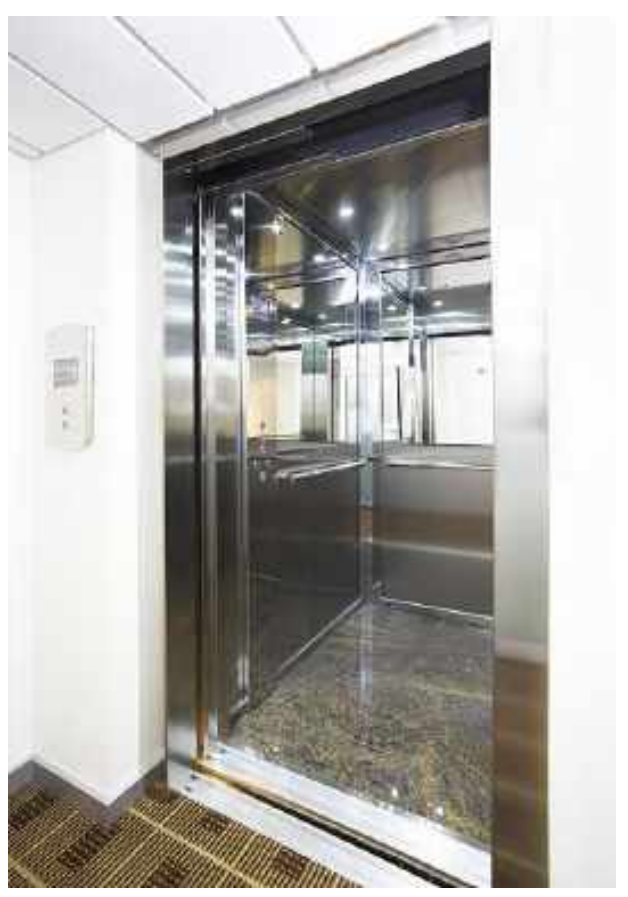

Рис. 33. Пассажирский лифт, соединяющий все палубы теплохода

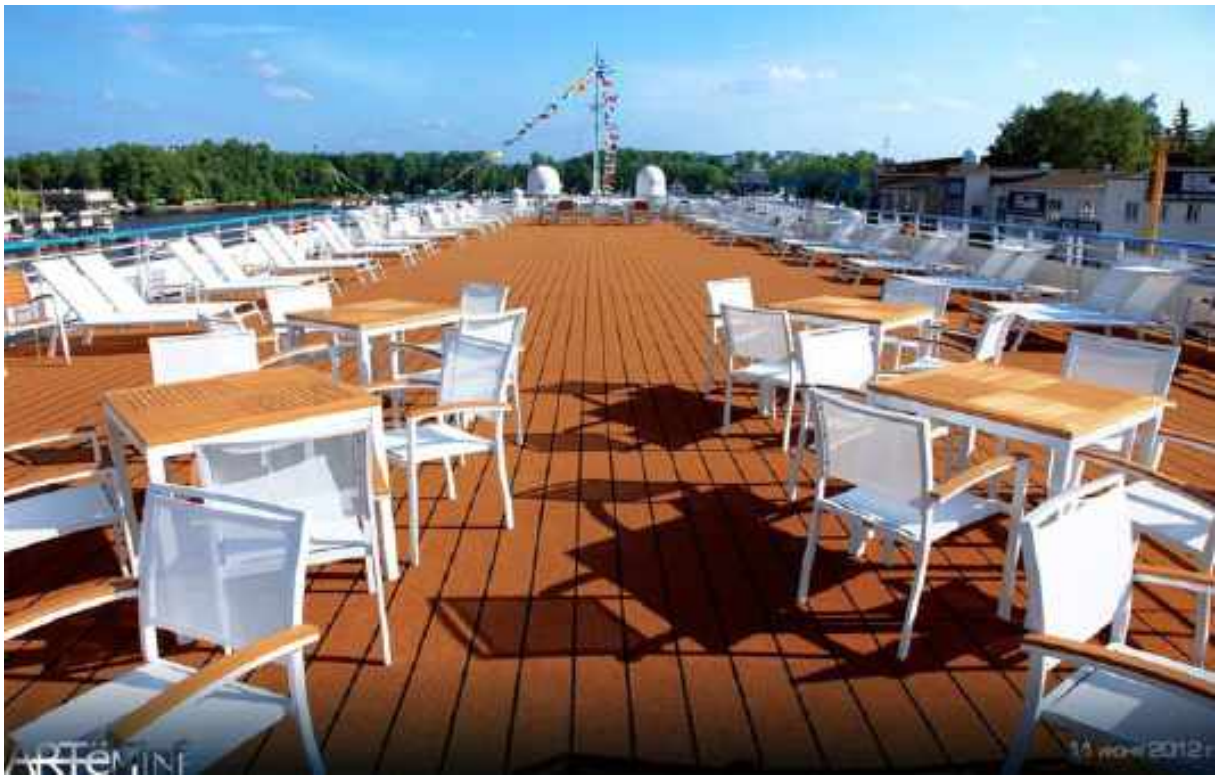

Рис. 34. Верхняя открытая палуба [12] 
ВІСНИК

ОДЕСЬКОГО НАЦІОНАЛЬНОГО МОРСЬКОГО УНІВЕРСИТЕТУ № 2 (59), 2019
HERALD

OF THE ODESSA NATIONAL

MARITIME UNIVERSITY № 2 (59), 2019

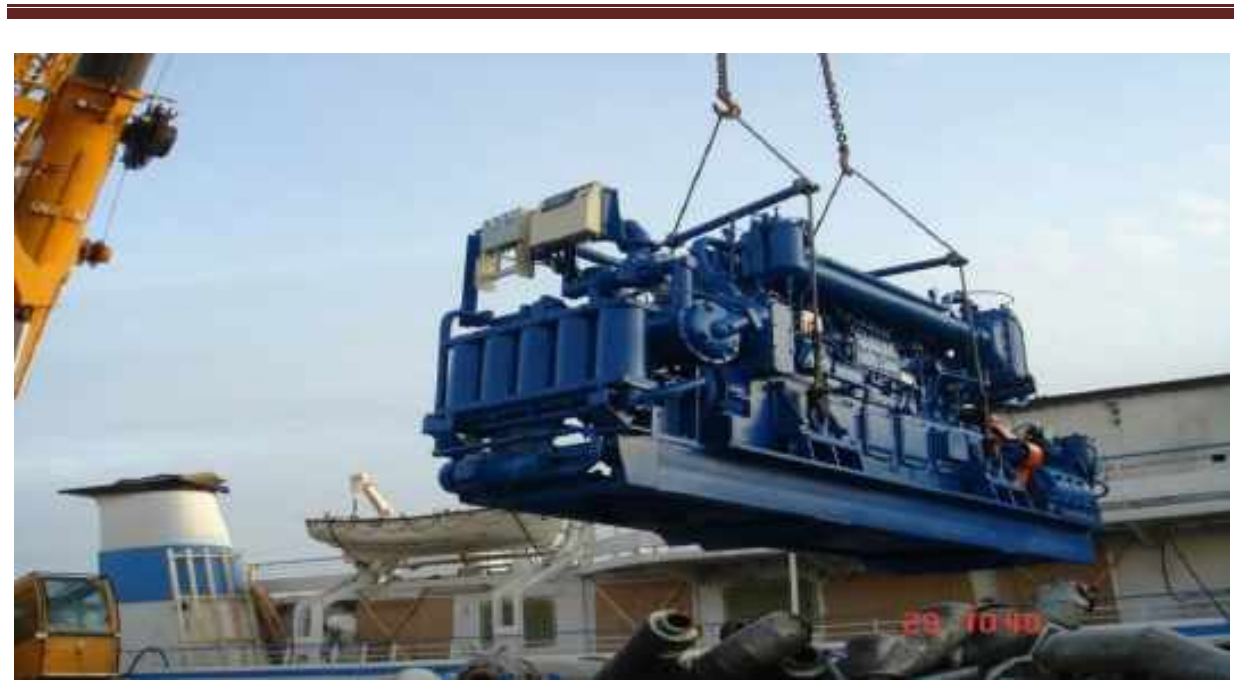

Рис. 35. Установка дизелей

ОАО «Завод «Волжский дизель им. Маминых»

Двигатели теплохода произведены в 2011-2012 годах ОАО «Волжский дизель имени Маминых». В состав СЭУ входит три главных дизель-реверс-редукторных агрегата мощностью по 337 кВт и три дизельгенератора мощностью по 300 кВт. Дизель-реверс-редукторные агрегаты ДРРАЗ2ЛП и ДРРАЗ2ЛЛ, используемые в качестве главного двигателя, собраны на базе дизельных двигателей 6ЧН21/21 с реверс-редукторной передачей РРП32 (мощность 337 кВт, обороты двигателя 1000 об./мин., обороты вала на выходе редуктор - 437 об./мин.).

Двигатели 6ЧН21/21 - это четырехтактные форсированные двигатели внутреннего сгорания, с водяным охлаждением, с непосредственным впрыском топлива, с турбонаддувом и промежуточным охлаждением наддувочного воздуха. Характерной особенностью машин является простота конструкции при высоких технико-экономических показателях, высокая ремонтопригодность в условиях судовой эксплуатации.

Реверс-редукторная передача РРП32 - зубчатая, механическая, несоосная, гидравлического включения с многодисковыми металлокерамическими фрикционными дисками, односкоростная с возможностью изменения направления вращения выходного фланца, имеет встроенный тормоз холостого хода, что значительно уменьшает время реверсирования и дает возможность с легкостью проходить шлюзовые участки.

Дизель-генераторы ДГС 300/1000 производства ОАО «Волжский дизель имени Маминых», установленные на теплоходе «Александр Грин», выполнены на базе дизельного двигателя 6ЧН17/20 и генератора фирмы Stamford (синхронного типа, с бесщеточной системой возбуждения и антиконденсатным подогревом). Дизель 6ЧН17/20 - морского исполнения и эксплуатируется как на море, так и на реке. Имея хорошие 
ВІСНИК

ОДЕСЬКОГО НАЦІОНАЛЬНОГО

МОРСЬКОГО УНІВЕРСИТЕТУ № 2 (59), 2019
HERALD

OF THE ODESSA NATIONAL

MARITIME UNIVERSITY № 2 (59), 2019

технико-экономические показатели, двигатель надежен в использовании, прост в эксплуатации и удобен в обслуживании. Дизель имеет подтверждённый расход топлива 145 г/э.л.с./час, полученный за счёт хорошей продувки и наполнения цилиндров. Для увеличения ресурса клапанов установлены механизмы поворота клапанов. Для повышения ресурса поршневой группы применено струйное охлаждение поршней. Привод топливного насоса высокого давления осуществляется через высокоэластичную пластинчатую муфту, обеспечивающую стабильность угла опережения впрыска и надёжность привода.

Система ДАУ и автоматики управления судовой энергетической установкой выполнена предприятием ОАО «Риатон-П» (г. Барнаул).

Винто-рулевой комплекс состоит из 3-х винтов фиксированного шага и 3-х обтекаемых рулей с управляемыми закрылками (рули типа Беккера). Для улучшения управляемости на малых ходах, при проходе шлюзов и при швартовках на судне предусмотрено носовое подруливающее устройство мощностью 207 кВт.

Экипаж и обслуживающий персонал из 62 человек размещается в одно, двух и трехместных каютах на нижней палубе (в корпусе судна) и в носовых частях главной и шлюпочной палуб. Спасательное устройство состоит из двух моторных спасательных шлюпок вместимостью по 14 человек каждая и 6 надувных самовосстанавливающихся спасательных плотов вместимостью по 25 человек каждый.

Судно соответствует повышенным стандартам экологической безопасности. На судне предусмотрена закрытая система сточных и хозяйственно-бытовых вод. Все сточные и хозяйственно-бытовые воды отводятся в сборные цистерны, также на судне имеется установка обработки сточных вод производительностью $90 \mathrm{~m}^{3}$ в сутки [5].

Анализ повышения качества обитания при модернизации и конверсии РКПС. Основной целью модернизации или конверсии является повышение качества обитания на борту. Для изучения этого вопроса был выполнен детальный анализ распределения площадей на судах, которые были модернизированы или подверглись конверсии по проектам Морского Инженерного Бюро, и сопоставление полученных результатов с данными исходных проектов (см. таблицы 3 и 4). При неизменных главных размерениях достичь стандартов береговых отелей 4-5* можно только за счет уменьшения пассажировместимости, именно поэтому все модернизированные или конверсионные РКПС могут принять меньшее количество пассажиров на борт, по сравнению с изначальными проектами. 
量

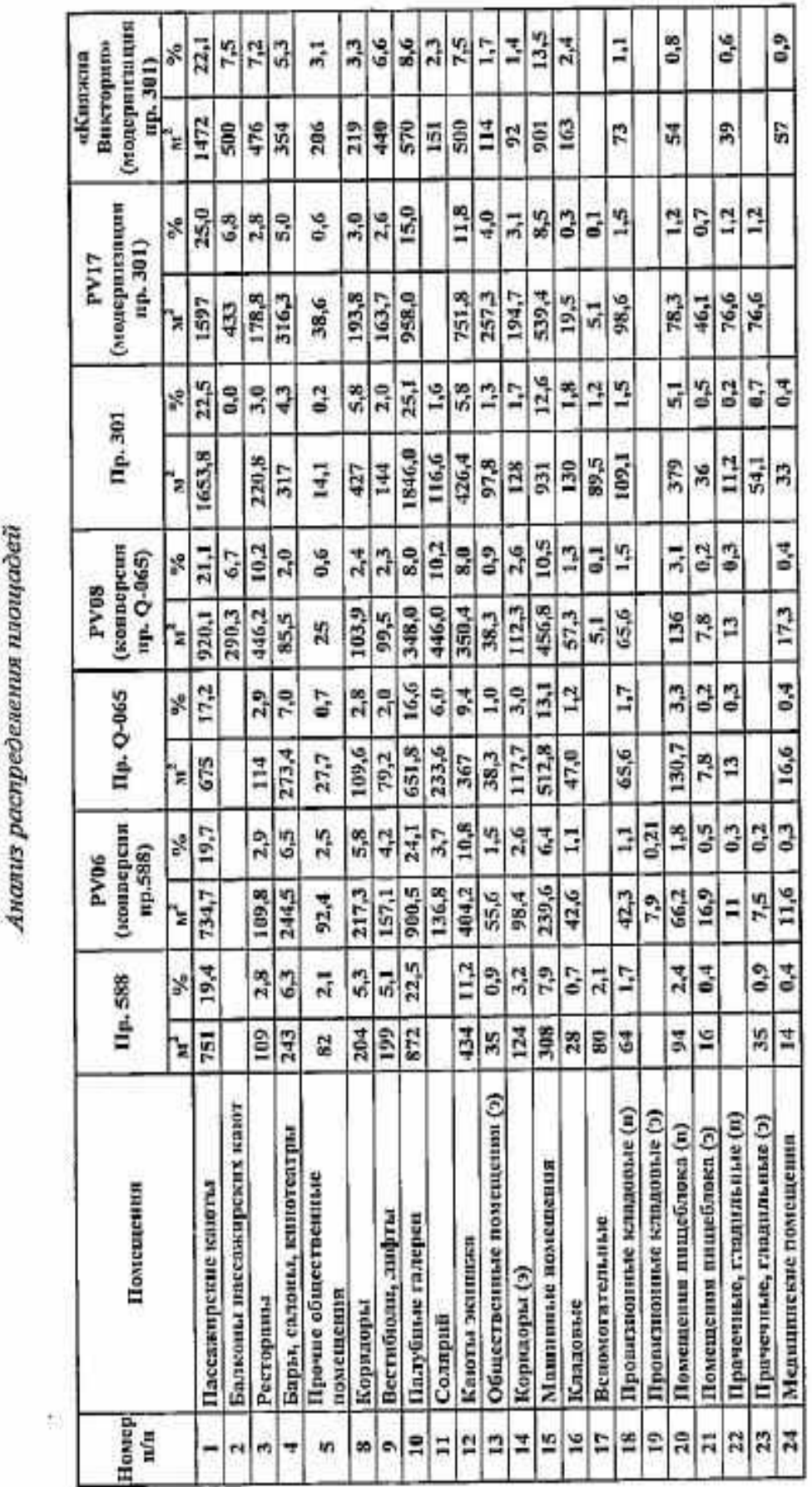


ВІСНИК

ОДЕСЬКОГО НАЩІОНАЛЬНОГО

МОРСЬКОГО УНІВЕРСИТЕТУ

№ 2 (59), 2019
HERALD

OF THE ODESSA NATIONAL

MARITIME UNIVERSITY

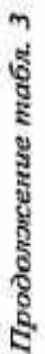

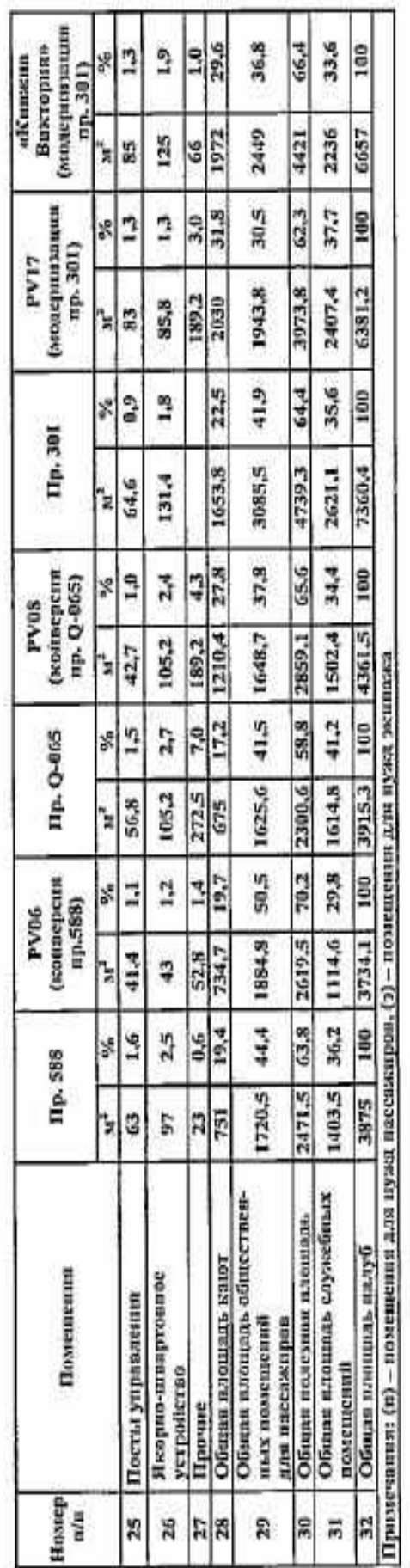

हू

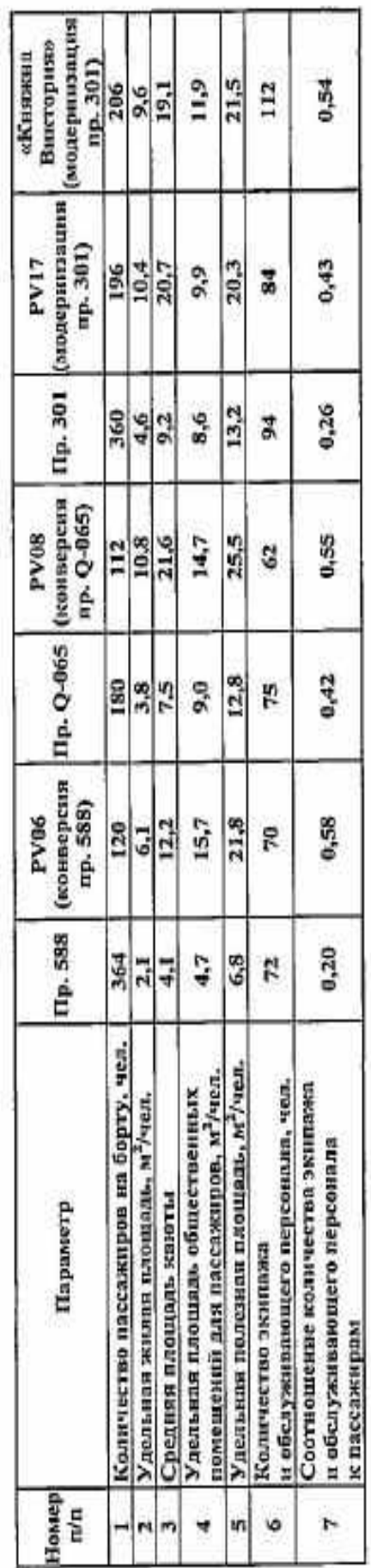


Средняя площадь пассажирской каюты на конверсионном РКПС проекта PV06 по сравнению с исходным судном проекта 588 выросла на $196,7 \%$ (с 4,1 м² до 12,2 м²), на конверсионном РКПС проекта PV08 по сравнению с исходным судном проекта Q-065 выросла на 188,2\% (с 7,5 м² до 21,6 м²), на модернизированном РКПС проекта PV17 по сравнению с исходным судном проекта 301 выросла на $125,5 \%$ (с 9,2 м² до 20,7 м²), на «Княжне Виктории» - на 108,4 \% (до 19,1 м²).

Удельная площадь общественных помещений на конверсионном РКПС проекта PV06 по сравнению с исходным судном проекта 588 выросла на 232,3\% (с 4,7 м²/чел. до 15,7 м²/чел.), на конверсионном РКПС проекта PV08 по сравнению с исходным судном проекта Q-065 выросла на $63,0 \%$ (с 9,0 м²/чел. до 14,7 м²/чел), на модернизированном РКПС проекта PV17 по сравнению с исходным судном проекта 301 выросла на $15,7 \%$ (с 8,6 м²/чел. до 9,9 м²/чел.), на «Княжне Виктории» - на $38,7 \%$ (до $11,9 \mathrm{~m}^{2} /$ чел.).

Удельная полезная площадь (площадь общественных помещений для пассажира и кают) на конверсионном РКПС проекта PV06 по сравнению с исходным судном проекта 588 выросла на $221,5 \%$ (с 6,8 м²/чел. до $21,8 \mathrm{~m}^{2} /$ чел.), на конверсионном РКПС проекта PV08 по сравнению с исходным судном проекта Q-065 выросла на 99,7 \% (с 12,8 м²/чел. до $25,5 \mathrm{~m}^{2} /$ чел.), на модернизированном РКПС проекта PV17 по сравнению с исходным судном проекта 301 выросла на 54,0 \% (с 13,2 м²/чел. до $20,3 \mathrm{~m}^{2} /$ чел.), на «Княжне Виктории» - на 63,0 \% (до 21,5 м²/чел.).

Причем заметно, что чем старее «объект» модернизации / конверсии, тем значительнее разница в полученных значениях.

При модернизации или конверсии РКПС наблюдается увеличение количества экипажа и обслуживающего персонала на одного пассажира, что также является нормой при повышении уровня обслуживания. Если на исходных проектах на одного члена команды приходилось 2,4-5 пассажиров, то на обновленных судах - 1,7-2,3.

Заключение. Обзор и анализ выполненных модернизаций и конверсий отечественных РКПС показал, что такие процедуры действительно эффективны: повышается качество жизни пассажиров на борту, улучшаются условия обитаемости, а в случае с конверсией - еще и повышается надежность эксплуатации РКПС в целом (в зависимости от заложенных в конверсию средств и целей).

Процедуры конверсии и модернизации могут быть рекомендованы отечественным операторам как процедуры, позволяющие продлить жизнь речным круизным пассажирским судам в условиях ограниченных финансовых возможностей. 
ВІСНИК

ОДЕСЬКОГО НАЦІОНАЛЬНОГО

МОРСЬКОГО УНІВЕРСИТЕТУ

№ 2 (59), 2019
HERALD

OF THE ODESSA NATIONAL

MARITIME UNIVERSITY

\section{СПИСОК ЛІТЕРАТУРИ}

1. Егоров А.Г. Анализ возможности реализаџии инноващионных решений на модернизированных и конверсионных речных круизных пассажирских судах // Труды НТК по СМК, посвященной 125-летию со дня основания ФГУП «Крыловский государственный научный иентр». СПб.: Крыловский государственный научный центр, 2018. С. 144.

2. Егоров А.Г. Анализ закономерностей списания речных круизных судов и прогноз состава речного флота с определением наиболее востребованных типов судов для конверсии и модернизации // Морской Вестник. 2019. № 1 (69). С. 21-27.

3. Егоров А.Г. Анализ круизного пассажирского флота // Материаль IX междун. научно-техн. конф. "Инновации в судостроении и океанотехнике». Николаев: НУК, 2018. С. 61.

4. Егоров Г.В. Перспективы круизов по рекам России // Морские вести России. 2013. № 13 (386). С. 12-16.

5. Егоров Г.В., Калугин Я.В. Опыт модернизаџии и строительства речных круизных судов с использованием элементов судов-доноров // Зб. наук. праџь НУК. Миколаїв: НУК, 2013. № 2. C. 4-9.

6. Интернет-сайm «Водный транспорт». URL: https://fleetphoto. $\mathrm{ru} /$ photo/249473/?vid=684 (дата обращения 18.02.2019).

7. Интернет-сайт «Водный транспорт». URL: https://fleetphoto. ru/photo/221302/?vid=4114 (дата обращения 18.02.2019).

8. Интернет-сайт «Водный транспорт». URL: https://fleetphoto. ru/photo/38909/ (дата обрамения 18.02.2019).

9. Интернет-сайт «Водный трансnорт». URL: https://fleetphoto. ru/photo/38931/ (дата обрамения 18.02.2019).

10. Интернет-сайт «Водный трансnорт». URL: https://fleetphoto. ru/photo/38928/ (дата обращения 18.02.2019).

11. Интернет-сайт «Водный трансnорт». URL: https://fleetphoto. ru/photo/38926/ (дата обращения 18.02.2019).

12. Интернет-сайт «Водный транспорт». URL: https://fleetphoto. ru/photo/38927/ (дата обращения 18.02.2019).

13. Сайт круизной компании «Luftner Cruises» / Ренновачия пассажсирского судна "Amadeus Diamond》. URL: http://www. lueftner-cruises.com/en/our-amadeus-fleet/ms-amadeus-diamond. html (дата обращения 18.02.2019). 


\section{REFERENCE}

1. Egorov A.G. (2018). Analiz vozmozhnosti realizatsii innovatsionnykh reshenii na modernizirovannykh $i$ conversionnykh rechnykh kruiznykh passazhirskikh sudakh [Analysis of possibility of realization of innovative decisions on modernized and conversed river cruise passenger vessels]. Trudi NTK po SMK, posvyaschennoy 125-letiyu so dnya osnovaniya FGUP «Krylovskiy gosudarstvennyi nauchnyi tsentr» (Proceedings of Ship Structural Design Sc-Tech. conference dedicated 125 anniversary from the foundation of FSUE «Krylov State Research Centre»). St. Petersburg, 144 [in Russian].

2. Egorov A.G. (2019). Analiz zakonomernostey spisaniya rechnykh kruiznykh sudov i prognoz sostava rechnogo flota s opredeleniem naibolee vostrebovannykh tipov sudov dlya konversii i modernizatsii [Analysis of trends of decommissioning of river cruise vessels and prognosis of structure of river fleet with definition of most demanded types of vessels for conversion and modernization]. Morskoy Vestnik (Maritime Reporter), 1 (69), 21 27 [in Russian].

3. Egorov A.G. (2018). Analiz kruiznogo passazhirskogo flota [Analysis of cruise passenger fleet]. Materialy IX mezhdun. nauchnotekhn. konf. "Innovatsii $v$ sudostroenii $i$ okeanotekhnike» (Proceedings of IX international Sc-Tech. conference «Innovations in shipbuilding and ocean technique»). - Nikolayev, 61 [in Russian].

4. Egorov G.V. (2013). Perspektivy kruizov po rekam Rossii [Perspectives of Russian river cruises]. Morskie Vesti Rossii (Russian Maritime News), 13 (386), 12-16 [in Russian].

5. Egorov G.V., Kalugin Ya.V. (2013). Opyt modernizatsii $i$ stroitelstva rechnykh kruiznykh sudov s ispolzovaniem elementov sudov-donorov [Experience of modernization and building of river cruise vessels with usage of elements of vessels-donors]. Zb. nauk. pratst NUK (Collection of scientific papers of Nikolayev University of Shipbuilding), 2, 4-9 [in Russian].

6. «Fleet photo» website. URL: https:/ffleetphoto.ru/photo/249473/ ?vid=684 (access date 18.02.2019).

7. «Fleet photo» website. URL: https:/fleetphoto.ru/photo/221302/ ?vid=4114 (access date 18.02.2019).

8. «Fleet photo» website. URL: https://fleetphoto.ru/photo/38909/ (access date 18.02.2019).

9. "Fleet photo» website. URL: https://fleetphoto.ru/photo/38931/ (access date 18.02.2019). 
ВІСНИК

ОДЕСЬКОГО НАЦІОНАЛЬНОГО

МОРСЬКОГО УНІВЕРСИТЕТУ № 2 (59), 2019
HERALD

OF THE ODESSA NATIONAL

MARITIME UNIVERSITY

№ 2 (59), 2019

10. «Fleet photo» website. URL: https://fleetphoto.ru/photo/38928/ (access date 18.02.2019).

11. "Fleet photo» website. URL: https://fleetphoto.ru/photo/38926/ (access date 18.02.2019).

12. «Fleet photo» website. URL: https://fleetphoto.ru/photo/38927/ (access date 18.02.2019).

13. "Luftner Cruises» cruise company website / Rennovation of "Amadeus Diamond» passenger vessel. URL: http://www.lueftnercruises.com/en/our-amadeus-fleet/ms-amadeus-diamond.html (access date 18.02.2019).

Стаття надійшла до редакиії 15.10.2019

\section{Рецензенти:}

доктор технічних наук, професор, завідувач кафедри «Машинознавства» Одеського національного морського університету А.В. Конопльов

кандидат технічних наук, доцент, завідувач кафедри «Теорія та проектування корабля ім. проф. Ю.Л. Воробйова» Одеського національного морського університету О.В. Демідюк 